NBER WORKING PAPERS SERIES

HUMAN CAPITAL, TECHNOLOGY, AND THE WAGE STRUCTURE: WHAT DO TIME SERIES SHOW?

Jacob Mincer

Working Paper No. 3581

NATIONAL BUREAU OF ECONOMIC RESEARCH

1050 Massachusetts Avenue

Cambridge, MA 02138

January 1991

This paper is a product of a research program funded by the National Science Foundation and the U.S. Department of Education via the National center on Education and Employment at columbia University. I am grateful to David Bloom and to Finis Welch for data and discussions, and to Lalith Munasinghe for conscientious research assistance. This paper is part of NBER's research program in Labor studies. Any opinions expressed are those of the author and not those of the National Bureau of Economic Research. 
NBER Working Paper \#3581

January 1991

HUMAN CAPITAL, TECHNOLOGY, AND THE WAGE STRUCTURE:

WHAT DO TIME SERIES SHOW?

AB8TRACT

The major purpose of this study was to detect effects of technologically based changes in demand for human capital on the educational and experience wage structure in annual CPS data, 1963 to 1987.

Major findings are:

1. Year-to-year educational wage differentials are quite closely tracked by relative supplies of young graduates, and by indexes of relative demand, such as research and development ( $R \&$ D) expenditures per worker, and ratios of service to goods employment. of these, $R$ and $D$ indexes account for most of the explanatory power. Indexes of (Jorgenson type) productivity growth and of international competition are significant as alternatives, but show weaker explanatory power.

2. The observed steepening of experience profiles of wages is explained, in part, by changes in relative demographic supplies (cohort effects), and in part by the growing profitability of human capital which extends to that acquired on the job. Evidence appears in the significance of profitability variables or in demand factors underlying them, given the relative demographic supplies in the wage profile equations.

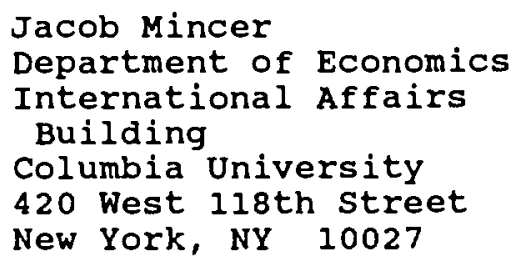




\section{HUMAN CAPITAL, TECHNOLOGY, AND THE WAGE STRUCTURE What Do Time Series Show?}

I.

1. Long-Term Stability and Short-Term Changes in the Profitability of Education

The effect of education on earnings was the initial and continues to be the central subject of research in the economic analysis of education. The gain in earnings associated with an additional year of education is viewed as a return on the investment costs of the additional year. This return, expressed as a percent gain in wages obtainable without the investment, is the educational (relative) wage differential or the "educational premium." The same annual return, expressed as a ratio to the investment costs is the (marginal) rate of return to education, a measure of education's profitability.

In competitive labor markets, higher wages associated with a higher level of education correspond to the greater productivity of that labor. However, with no other changes, increased supplies of educated labor reduce its marginal product, therefore the educational wage differential. Thus rapid growth of education relative to demand for it reduces its profitability while slow or no growth increases it. Changing profitabilities in turn represent incentives for subsequent changes in supply: enroliments decrease when profitability declines, and once the market experiences a significant decline in the relative supply of educated labor, educational wage differentials return back to a normal or equilibrium ${ }^{1}$ level of profitability. Rates of return to education can also increase with unchanging supplies, when demand for educated labor increases, either because demand for its services or products increases or because its productivity grows as a result of technological changes. Again supply adjustment is induced as described before, pushing profitability rates back to equilibrium. The time lag between the impulse of high or low profitabilities and their return to normal involves a supply adjustment which tends to be 1 Equilibrium is best defined as the equality of rates of return on alternative capital investments. 
lengthy: For example, in response to an increased profitability of college education more high school graduates enter college. It takes at least four years to graduate and several more years until the increased supply of college graduates reduces the wage differential to a level at which relative supplies stabilize if no further impulses intervene.

The usual estimates of rates of return to an additional year of education run between 5-10\%. These magnitudes are consistent with the investment interpretation, as they are comparable to rates on alternative capital investments. Sporadic estimates of rates of return to education in the U.S., based mainly on data in the late 1950's and the 1960 's left an impression of temporal stability. However, the decline in the educational wage premia in the mid- to late 1970's (Freeman, 1976) and even greater rebound in the 1980's (Murphy and Welch, 1989) led to intensive on-going research on what seem to be unprecedented changes in the past two decades in the U.S.

Data on long-run changes here and abroad (Becker 1975, Psacharopoulos, 1985) indicate relatively small reductions in the rates of return to education over many decades of growth in educational attainment.

Two questions are posed by these facts on educational wage premia: (1) What explains the absence of a significant downward long-term trend in the profitability of education, given massive increases in supplies of educated workers?; and (2) What explains the rather dramatic swing in the wage premium in the U.S. during the past two decades?

The economists' answer to the first question is a conjecture based on a generally accepted hypothesis that downward pressures on profitability due to increase in supply of educated labor are counteracted by long-term growth in the demand for educated labor. In this view, the massive growth of educational attainment represents, in large measure, a continuous response to growth in profitability of education engendered by growing demand. Profitability is kept in check - near equilibrium levels - as an outcome of these 
private and social supply responses. Unfortunately, empirical work on factors generating long-term trends in the demand for educated workers and on documenting the supply responses is only in its infancy. More work has been done on shorter term fluctuations in demand and on supplỳ responses in particular occupations (mainly by Freeman).

It is generally acknowledged that the basic reason for the secular growth of education is economic growth. That education, conversely, contributes to economic growth is not a contradiction - the relation is partly reciprocal. The positive effects of economic growth on educational attainment are due to growth of income which leads to increases in private and public expenditures on education, as it does to an increase in consumption expenditures on most other goods and services. This is so whether education is viewed as skill or culture enhancing. This income effect obviously results in an increase in the supply of educated workers with consequent downward pressure on profitability. The counteracting growth of industrial demands for educated workers originates from the production side: (1) the growth of quantity and quality of physical capital (machines and equipment) per worker; and (2) improvements in technology which can increase output without changes in inputs, that is increase total (or multi-) factor productivity. Both are mainsprings of economic growth and each one generates increases in demand for human capital under plausible conditions: (1) For growth of physical capital to have this effect it must be less substitutable (or more complementary) for educated (skilled) than for less skilled labor. Econometric studies by Griliches (1969), and by Hamermesh and Grant $(1979,1981)$ appear to support this hypothesis of a positive skill bias of physical capital accumulation. (2) For new technology to have a similar effect, it must be skill-biased. A growing body of recent economic research is consistent with the proposition that more schooled and trained workers more readily muster the new technologies. Thus, Bartel and Lichtenberg (1987) using Census data report that relatively more educated workers are employed in those manufacturing industries (in 1960, 1970, and 1980) where capital 
equipment was newer and R \& D (research and development) expenditures were more intensive. That this is due to a greater demand for educated workers is confirmed by findings of higher relative wages of better educated workers in such industries, compared to other industries.

These findings were reported in my recent study (1989) of PSID data in which I related indices of demand for educated workers, such as their utilization, relative wages, wage growth with tenure, turnover, and unemployment, to decade-long averages of the pace of technology. For the latter I used Jorgenson's total factor productivity (TFP) indexes. $^{2}$ The cross-industry findings showed higher levels of demand for human capital in progressive sectors in the 1960's and 1970's. Similar results concerning effects on relative educational wage differentials within industries were found in Census data by Gill (1989).

In order to explore the effects of capital-skill complementarily I used the sectoral (decade long) growth of capital intensity as a variable, in addition to the productivity growth variable. The effects on utilization of educated labor were positive, but no relative educational wage effects were visible within sectors. The effects may be confounded, as newer vintages of capital contain new technology. Consequently, the skill bias of technology may to some extent reflect the skill bias of capital and conversely.

In a previous study (with Higuchi, 1988) we have shown that differences between the U.S. and Japan in rates of technological change (measured by national and sectoral TFP indexes) can explain why wage structures (and turnover rates) differ in and between the two countries.

2 A major merit of the Jorgenson TFP indexes for the purpose at hand was their construction as residuals from quality adjusted changes in capital and labor growth accounting. Quality adjustment of the labor input eliminates (or, at least, minimizes) the human capital content of the residuals thereby largely eliminating a spurious correlation between the residuals and the inputs that would otherwise occur. The decade long averages also reduce much of the year-to-year error and the effects of the business cycle. 
All the studies cited are sectoral (industry) cross-sections. While they are strongly suggestive in showing a positive association between the pace of technology in a sector (measured by various proxies) and indices of relative demand for educated workers in the sector, they do not - by themselves - establish a causal relation nor the direction of causality. For the interpretation to be more compelling, the analysis must be cast in a time series format to determine whether changes in the pace of technology are followed by corresponding changes in educational differentials, and whether inferences based on sectors hold up in the aggregate - a notion that is often misleading.

The cross-section studies point to technology induced demand for human capital as a likely answer to the question about long-term stability of as well as changes in the rate of return to education. With currently available data a time series approach appears to be feasible and promising for verifying these hypotheses and for estimating the effects of changing demand for human capital.

The question concerning causes of the pronounced shorter term swings in educational wage premia during the past 2-3 decades requires attention to fluctuations in supply and demand for educated labor, rather than to trends in them. Demand or supply impulses can generate such fluctuations. These can be relatively lengthy, as adjustments proceeding through the educational pipeline take time. If the pace of technology varies over time, its effects as demand "shifters" ought to be discernible in the time series of the past 25 years.

Several exogenous ${ }^{3}$ events ("shocks") are likely to have caused the gyrations in supply and demand and consequently in rates of return to education in the recent period: (1) On the supply side: Influx of the baby boom cohorts into the labor market during the 1970 's, and especially of college graduates. Above trend growth of income and of public 3 An event is exogenous if it affects other events under consideration, but is not affected by them. 
subsides to higher education in the 1960's are basic to the increased supply of college graduates, which was additionally accelerated by the Vietnam War draft exemptions. (2) On the demand side: Productivity growth which was substantial in the 1950's and 1960's collapsed to low levels in the 1970's, partly as a result of the emergence of oil cartels and the oil price shocks, but largely for reasons not yet well understood. A partial recovery was evident in the 1980's, but its course or measurement seems uncertain. The suggestion that the pace of technology is implicated in the short as it is in the long run, is a major motivation of the present study. (3) Another possible factor on the demand side, first pointed out by Murphy and Welch (1988) is the growth of world trade hence of international competition which became pronounced in the 1980's. This resulted in losses of U.S. exports and growth of imports which substituted for domestic production (automobiles and electronics being the most visible examples). The reduced demand for labor put downward pressures on wages and employment in the affected sectors, which are generally less education intensive than other sectors (such as services, finance and insurance, etc). The decline in union density which was probably induced by these developments, is another, but not independent, reason for the relative decline in wages of less educated (high school or below) workers.

It is clear that in order to test the relation between technological change and the demand for education in a time series of wage differentials, it is also necessary to take into account changes in demography and in relative educational supplies. In other words, although the initial purpose of this work is to ascertain the reality of technological skill bias in historical changes rather than in cross-sections, empirical research necessitates an investigation of the major forces at play including technological change in the recent changes in the wage structure. 


\section{Skill Differentials in Education and Experience. and Changes in Them: Some}

\section{Hypotheses}

Since labor market skills are acquired by learning at school and by learning on the job, changes in demand for skills should affect both wage differentials by education as well as those by labor market experience: Increases in the latter need not, however, be of the same size at different levels of education. For example, if technology is biased toward newer vintages of higher education, the experience differential may be smaller at college than at high school levels. Similarly, reductions in demand for less educated workers resulting from international competition would affect primarily employment and wages of younger workers, with lesser skill and seniority. As a result the experience differential at lower (high school or less) levels would increase relative to the experience differential at college (or above) levels.

The influx of "baby boomers" and especially of college graduates into the labor markets of the 1970's stimulated a research focus on effects of changes in relative supplies on relative wage differentials. The growth of numbers of college graduates relative to numbers of less educated workers, in the 1970's narrowed the (percent) wage differential between college and high school graduates. With the apparent excess supply of college graduates, the U.S. labor force appeared to be "overeducated." At the same time, the pronounced increase in the number of young relative to older workers, the "baby boom" effect was to widen the experience differentials in wages at all levels of education, and especially at the college level.

The bigger increase of young relative to older workers at the college level was mainly a result of the more rapid increases of numbers of college graduates compared to high school graduates. In other words, changes in relative educational supplies which 
mainly (initially) affected young cohorts automatically affected relative age distributions differentially in the two groups.

The greater "youthening" of the college group compared to the high school group is, of course, a result of accelerated college enrollments. Entry of large young cohorts tend to reduce wages of young workers relative to wages of older workers only if substitution in production between older and younger workers is imperfect. No experience differential would arise (though wages of all would be reduced somewhat) if substitution were perfect. If substitution between younger and older workers is weaker among those educated, this could be an additional reason for the greater widening of the age-differential in wages ("steepening of the experience profile") of college than of high school graduates in the 1970's - simply as a result of demography and not of "overeducation." And this purely demographic effect would at the same time reduce the educational wage differential or the college "wage premium" among young workers.

As "baby bust" cohorts entered the labor market in the 80 's and relative supplies of college graduates stopped growing or even decreased, opposite implications should have emerged. Wage profiles should have flattened - more so at college than at high school levels, while the college premium should have risen.

On the demand side, decline of the pace of technology in the 1970's would intensify the decline in rates of return of college graduates already attributed in part to increased supply. Renewed growth of demand for educated workers based on skill biased technology in the 80 's coupled with declines in demand for less educated workers due to international competition would produce a reversal (growth) in the college wage premium. 
The hypotheses spelled out here are not new. They are partly based on findings of current research of a number of labor economists ${ }^{4}$ and partly on conjectures which have not as yet been verified. In particular, the role of technology has not been empirically estimated - a major motivation here - nor have analyses been framed in a continuous (yearto-year) time series which is attempted here.

Before I proceed to the empirical analysis, a closer look at the meaning of experience differentials in wages is helpful:

The growth of wages with experience as a result of learning on the job is the major factor affecting working age differentials in wages (the "wage profile") according to human capital theory. The ratio of wages of older to those of younger workers which we study here does not describe wage progress over time within a cohort (a longitudinal concept) but wage differences across different cohorts at a given time (a cross-sectional concept). Differences between the longitudinal and cross-sectional constructs are due to (1) economic growth and (2) changes in age distributions over time. Economic growth makes the longitudinal profile slope upward even if no learning takes place. Consequently, with stable age distributions, the cross-sectional profile may best reflect the expected wage payoff to learning on the job. ${ }^{5}$

This payoff increases with experience, that is the slope of the cross-sectional profile is steeper in one period than another because more learning (training) takes place, or because the acquired learning has become more profitable. Consequently, once relative demographic supplies are held constant, the experience-wage differentials should move in the same direction as the profitability of education, assuming that the demand for human

4 Aside from the initial and continuing work of Murphy and Welch (1979), a number of papers were presented in at least three conferences in 1989 at Brookings, NBER, and AEI. A special focus on less skilled workers is provided by Blackburn, Bloom, and Freeman (1990).

5 For simplicity of exposition, I ignore possible non- neutralities of economic growth with respect to age. 
capital affects both that acquired at school and on the job. In the empirical analysis, therefore, both relative supply variables and demand variables which affect profitability, should play a role in creating changes in experience wage differentials.

In this connection there is a question of subsidiary interest: Does the demographic change affect learning processes, that is investments in training, and in what direction? Two different theories predict opposite effects: One holds that the opportunity costs of training were reduced by the reduction in wages of the young "baby boom" workers in the 1970 's. The consequent increase in training should have increased longitudinal wage growth in addition to the cross-sectional steepening due to the demographic effect (Welch, 1979). The opposite theory maintains that a decrease in the ratio of teachers (trainers, older workers) to students (trainees, young workers) results in less training per worker (Berger, 1984) and so a flatter longitudinal profile is possible despite the steeper cross-section profile due to the baby boom. The empirical analysis should shed some light on this matter as well.

\section{II.}

\section{Empirical Analysis: Data and Dependent Variables}

As already explained, casting the link between technology and human capital in a time series framework involves an investigation of the changes in the U.S. wage structure in the recent decades for which annual data are available. The changes which continue to attract attention of economists and of others were summarized as : (1) A near cessation of growth of real wages since the 1970's coupled with (2) Large, decade long swings in wage differentials among skill groups in the work force. In particular, the average near-cessation of wage growth was accompanied by declines in real wages of workers with below average skill and education, especially in the 1980's; and (3) Wage differentials by age appear to have risen throughout most of the period. Other changes which are not analyzed in this 
paper are: the switch from a stable sex-differential in wages prior to the mid-seventies to a subsequent narrowing of it, and the exact opposite in the black-white wage differentials. These issues are excluded by restricting the data to white male workers. The current report utilizes data from the March issues of the Current Population Survey. The data are in the form of averages of logarithms of hourly wages of white, male workers in each single year of experience, with 40 such years in each of the six education groups, in each calendar year from 1963 to 1987.6

The wage structure to be analyzed is represented by differences in logarithms of wages across education and experience (age) groups. Such education and experience differentials in wages could be represented as continuous variables which enter nonlinearly into the "human capital" wage function. The coefficients of schooling ("dummies") and of experience in such a function fitted to the data in which logarithms of wages are the dependent variable would indicate both educational and experience (relative) wage differentials, or wage premia of an additional year of each. Time changes in these coefficients would provide time series of the changes to be explained.

However, such a procedure is too restrictive, and can distort the measurement of wage differentials and, especially, of their time pattern, if the shapes of the experience wage profiles of the different education groups are different and change differentially over time, which is the case. A preferred non-parametric approach is to measure the educational wage differentials by (logs of) ratios of wages of higher to lower education levels in the 6-10 years of experience groups. This $(\mathrm{log})$ ratio or wage premium per year is the best approximation of the rate of return to education, as it is measured roughly at the "overtaking stage" of the working life. ${ }^{7}$ The cross-section (log) ratios of older to younger

6 I am grateful to Finis Welch for providing the data.

7

This is the period when the net contribution of job training to wages is close to zero, thus revealing only schooling effects on wages (Mincer, 1974). For this wage premium to equal the rate of return, the 
workers within an education group, in turn, represent the experience differentials, in wages. I use wages of workers with 21-25 years of experience in the numerator and wages of those with 1-5 years of experience in the denominator. Basically, this ratio (in log's) labeled (Dif 51) measures the cross-sectional increase from starting wages in a given education group to the level at which further increases are rather small. As mentioned before, this crosssectional increase does not correspond to the actual growth of wages within a given cohort, unless the age distribution is fixed and the level of wages does not change over time differentially at the various experience levels. Some attempt is, therefore, made also to explore the within cohort wage growth of young workers over several years of their actual experience.

Although our complete analysis utilized information on 6 education groups (years of school $<8,8-11,12,13-15,16,17+$ ), we focus primarily on the wage differential between college and high school graduates. The average education level within all other groups changed over time and this would blur the analysis. At any rate, the big differences and changes appear in the dichotomy between lower levels ( 12 or less) and post-secondary education, and the bulk of that is most clearly captured in comparing graduates of precisely 12 years (high school graduates) with those of 16 years of schooling (college graduates). Indeed, most of the recent studies focus mainly on this comparison for analyses of educational differentials and age (or experience) differentials.

The changing structure of educational and age (experience) wage differentials is portrayed in Fig. 1 and 2. Fig. 1 shows the changing (percent) wage differential (per year) between college and high school graduates who had (6-10) years of work experience. This differential rose between 1963 and 1968, it then declined to about half size by 1979 and rose steeply thereafter, more than recovering lost ground by 1986. denominator of the ratio has to include direct costs in addition to the opportunity costs, represented by the
lower level wage. 
Fig. 2 shows the changing experience differential in wages (difference in log-wages between older and younger workers) for high school graduates in graph marked $\mathrm{H}$ and for college graduates in graph marked C. Among high school graduates, this experience "premium" rises about $25 \%$ from the 60's to the 70's and continues to rise about twice as rapidly in the 1980's. Among college graduates, the pattern is of a steep (about 50\%) rise from the late 60 's to the early or mid 70's, and a rough plateau (slight decline followed by slight increase) thereafter.

It is important to keep in mind the components of the (log) ratios shown in Fig. 1 and 2: These are average levels of wages for groups with (1-5), (6-10), and (21-25) years of labor market experience of male high school and college graduates. All of these wages rose in real terms before 1973, though a bit faster for college graduates. After 1973, they declined among young high school graduates, ceased rising for older high school graduates but continued to rise for college graduates. ${ }^{8}$ Thus when increases in rates of return to college graduates are attributed to increases in relative demand, the latter consists both of increases in demand for college graduates and decreases in demand for high school graduates.

\section{Independent Variables: Concepts and Data}

To the extent that workers differing in education and in age (experience) are imperfect substitutes in production, relative supplies exert a negative effect on relative wages. Relative numbers of all college graduates among all males in the population aged 18-64 or of young college graduates among all young people (young defined here as 20-29 30 years of age) are used as measures of relative supply. ${ }^{9}$ Fig. 3 shows that the relative

8 The patterns of change in average wages differ somewhat depending on the definition of the average: Because dispersion (inequality) in wages increased within groups during this period, arithmetic averages show greater increases and smaller declines, while the logarithmic averages, used here, show smaller increase and greater declines (Kosters, 1989). 
supply of young college graduates just about doubled between the early 60's and mid 70's accelerating between 68 and 76 . Growth of supply stopped subsequently; indeed the supply of college graduates declined somewhat from 76 to 81 and rose mildly thereafter. In contrast, the relative supply of high school graduate declined mildly until the mid 70's, rose subsequently (as fewer students proceeded to college) and stabilized since about 1982. These changes are consistent with the changes in the wage differentials between college and high school graduates (Fig. 1) but only partially explain the latter, as the regression analysis shows.

Relative supplies of young and older workers, among high school and college graduates respectively, are shown in Fig. 4. These are ratios of numbers of young (age 20$29)$ to all graduates with the same educational level. The growth of young (relative) to all college graduates is rapid (about 50\%) between 1964 and 1974. The subsequent relative decline is equally steep and continuous after 1977. Clearly, a steepening of the college cross-section wage profile down to the mid or later 70's is expected on this account, and is indeed observed. But instead of declining, the ratios of wages of older to younger college graduates subsequently stabilize (Fig. 2) Changes in relative supplies of young high school graduates are milder: After a slight decline in the 60's, the proportion increases mildly until about 1980, and declines mildly subsequently. Again the corresponding changes in the wage profile by age (Fig. 2) are consistent up to the late 70's, but the continued and strong steepening of the profile thereafter is inconsistent with the expected effects of relative supplies.

Of primary interest among variables affecting relative demands for skills is a measure of the pace of technology. This factor, according to previous work, ${ }^{10}$ is skill-

variables which affect both relative employment and wages of specific subgroups (here white). This may be an overly cautious approach.

10 As referred to Bartel-Lichtenberg, Gill, Mincer. 
biased. It widens the educational wage differentials when the pace quickens. In the study of the effects of technological change on the demand for human capital (skills) across industrial sectors I utilized indexes of growth of multi-factor productivity (PG) constructed by Jorgenson et al (1987). Their major merit for the purpose at hand was that they represent changes in productivity, given quality-adjusted labor and capital inputs. This means that the residual which measures growth in productivity is not attributable to human capital thus avoiding a spurious correlation between the two variables. To the extent that the residually measured productivity growth is affected by technology, it may serve as a proxy variable in relating technology to changes in demand for human capital. The well known problem with the productivity growth indexes is that they reflect other factors than technology such as the accretion of mundane know-how (learning by doing) in work skills and capital equipment, economies and diseconomies of scale, business cycles in capacity utilization and labor hoarding. Perhaps worst of all is the pronounced year-to-year volatility, reflecting errors of measurement due to the residual nature (differences between output and input growth) of this statistic.

For decade long cross-sections, averaging the productivity indexes over a decade alleviated both the volatility and the business cycle distortions, leaving a usable, albeit imperfect empirical variable. However, the problem is more acute for annual time series analysis in the present study. A partial and unsatisfactory (arbitrary) solution is the use of subperiod averages or moving averages of the Jorgenson residual. Subperiod averages provided by Jorgenson and Fraumeni are shown in Fig. 5. A preferred alternative index of the pace of technology in the current study is based on annual aggregated expenditures on R \& D (research and development). The Bartel and Lichtenberg cross-section study (1987) showed that sectoral (industry) R \& D intensity (ratio of R \& D expenditures to sales) could serve as an index of demand for educated labor-affecting its utilization and wages in the industry cross-section. 
The conceptual advantage of $\mathbf{R} \& \mathbf{D}$ measures is that they more directly represent sources and application of new technology to productive processes, rather than their partial reflection in productivity growth, even if the latter were measured without error. As many studies have shown, effects of $R \& D$ on productivity growth are substantial. About one third of multifactor productivity growth is attributable to $R \& D$, according to a recent BLS review (1989). The impact, however, is likely to vary over time and across industries, especially as between privately and governmentally sponsored R \& D. A weakness of the $R$ \& $D$ index at the sectoral level is that it leaves out inter-industry spillovers which augment the $\mathrm{R} \& \mathrm{D}$ effects in the aggregate. For the purpose of the present study, conducted on the aggregate level, sectoral differences and spillovers cause no problems. Neither does the distinction between privately and governmentally sponsored R \& D create problems, since the effects on demand for educated labor - if the innovations are skill biased - does not depend much on the particular application of the new technology: In all cases various sources of demand compete for the same supply of, say, engineers and scientists. Fig 6 shows the time series of real annual expenditures per worker ${ }^{11}$ on $R$ \& D from all sources, based on the BLS (1989) data.

The time series of R \& D per worker shown in Fig. 6 has some similarity to the step function of the PG index (Fig. 5), mainly in the decline from the late 60's to about 1980. But the rise thereafter is much smaller for PG than for $R$ \& $D$, suggesting a weakening effect of the latter on measured productivity growth, but not necessarily on the relative demand for educated labor. Indeed, the time pattern of $R \& D$ (Fig 6 ) is strikingly closer to the pattern of educational wage differentials shown in Fig. 1 then to the PG series in Fig. 5.

11 Intensity of $\mathrm{R} \& \mathrm{D}$ per worker is clearly a more appropriate variable in affecting demand for labor quality than its intensity per dollar of GNP. 
Two other indexes of relative demand for educated workers are: A measure of the impact of the growth of international trade, the net balance of merchandise trade as proportion of total output (RNE), shown in Fig. 7. Here losses of exports and replacement of domestic production by import reduced demand for labor, mainly in goods producing (manufacturing) industries. The affected sectors are less education intensive than service producing industries. The decline in unionism, especially important in manufacturing industries is likely to have been a result of declining demand for labor in them, contributing to the widening of the educational wage differential in the 80 's. It is not used here as a variable because of its suspected endogeneity. Another variable that is used, despite its partial endogeneity is the ratio of service to goods employment (RSG), shown in Fig. 8: Service industries are the major employer of educated workers. Growth of service relative to goods employment is a longer term trend which appears to reflect demand more than supply trends, as is partly evidenced by the differential growth in real wages in the two sectors.

The growing demand for skills in service jobs is partly driven by the growth of information technologies. This is best illustrated by the growing use of computers. The number of computer workstations has increased from less than 1 million in 1976 to 28 million in 1986, or from 15 to 450 per thousand white collar workers - roughly doubling the use per worker every two years (Cyert and Mowery, 1987).

The negative export balance was small prior to the 1980 's, but grew rapidly in the past decade. The ratio of service to goods employment, however, shows mainly a continuous upward trend over the whole period (and before).

Note that the relative supply variables are different in the analysis of the educational wage structure and in the experience wage structure. But the relevant demand variables are likely to be the same as they affect the profitability of human capital acquired 
at school and on the job, especially if their impact is stronger among younger than among older workers. One demand index, as yet not mentioned, which may affect the experience differentials and the educational differentials in wages is the business cycle. As indexes of the latter I tried to utilize unemployment rates (Fig. 9) or capacity utilization rates.

\section{REGRESSION ANALYSIS}

Table 1 lists the variable employed in the regressions, their abbreviated symbols, as well as their means and standard deviations. Their construction and sources are indicated in Table 1A. We now turn to the description of findings, showing the "effects" (regression coefficients) of the hypothesized explanatory variables on (1) educational wage premia, and on (2) experience wage differentials, over the 25 -year period for which data were collected.

\section{Educational Wage Premia}

Table 2 presents the regression coefficients for the college wage premium (WRAT) the percentage wage gain per year of college, at the "overtaking stage" (6-10 years) of work experience. More precisely, the dependent variable is the difference in the average logarithms of wage rates per hour of college and high school graduates, based on March surveys of the Current Population Survey (CPS).

Equation 1 (col. 1) features the effects of the relative educational supply variable (RES) (fraction of population age 20-29 who are college graduates), the Jorgenson productivity index (PG), and (RNE), the net export balance (as a fraction of GNP). The explanatory power, measured by the adjusted $\mathrm{R}^{2}$, increases from .68 to .80 in equation 2 (col. 2) in which two variables are added: The demographic variable (DR) measuring the numbers of young people (ages 20-29) as a fraction of all (ages 18-64) in all education groups combined, and the relative demand index (RSG), the ratio of employment in service producing to goods producing industries. 
The relative supply of college graduates (RES) does indeed exert a negative effect on the wage gains to college education, holding demand variables fixed. The demand variables, in turn, also exert the theoretically expected effect. Thus in equation (1) the (Jorgenson) productivity growth variable has a positive effect presumably by increasing the demand for college graduates and so does the export deficit, by reducing wages of high school graduates.

In equation (1) the relative supply variable (RES), the fraction of young college graduates among all young people, does not take into account the context of baby boom, bust, or of a steady aggregate age distribution. In equation (2) the additional demographic variable (DR) representing the aggregate age distribution does, indeed, have a negative effect on the wage differential, at (6-10) years of experience, consistent with the hypothesis that there is less substitutability between young and experienced college graduates than between young and older high school graduates. The additional relative demand variable in (2) is the ratio of service employment to goods employment (RSG). It shows a positive effect on the college wage premium, reflecting a skill bias in the growing demand for services as well as the depressing effect of international competition on enmployment and wages of less educated workers in manufacturing. Inclusion of this variable in eq. (2), therefore, appears to replace (eliminate) the net export variable and weaken the productivity growth variable.

Although the explanatory power is significantly increased in eq. (2) compared to eq. (1), we should not reject the validity of the technological (PG) and international trade (RNE) demand factors, especially as they may, in part, represent the background influences affecting the employment ratio (RSG).

In equation (3) an alternative (to $P G$ ) measure of the pace of technology affecting the demand for human capital is provided by the ( $\& \& D)$, research and development 
expenditures per worker. ${ }^{12}$ This is a sum of private and of government expenditures on $\mathbf{R}$ \& D. Although studies indicate that government expenditures have a lesser effect on aggregate productivity growth than private expenditures do (BLS, 1989), the effect on demand for higher level workers does not depend on the source of demand. Indeed, when the two components are put separately into the regression, their coefficients are quite close. The time pattern of the (combined) $R \& D$ variable is remarkably similar to the time pattern of the college wage premium, when the former is lagged two or three years. ${ }^{13}$ Consequently, this variable dominates (eq. 3), and jointly with the relative supply (RES) and the relative employment variable (RSG) which remain significant, yields the strongest explanatory power for eq. 3 compared to the preceding ones $\left(R^{2}=.90\right)$.

The (aggregate) unemployment rate variable (u) was not significant in any of the equations. That equation (3) tracks the time pattern of the profitability of college education quite closely is shown in Fig. 10, where the broken lines are the values predicted by the three variables in regression (3). Some of the "saw-tooth" fluctuations in the actual values of college wage premia (solid line) are due to measurement errors, so the predictive power of the equation is likely to be even stronger than appears.

Additional insights on the way variables in Table 2 affect college (relative to high school) wage premia are provided by considering the effects of these variable on the components of the comparison, that is on levels of wages of high school and of college graduates, separately. This is done in Table 3 both at starting levels (1-5 years) and advanced levels (21-25 years) of experience of the two education groups. The skill bias of the demand indexes of technology is quite apparent in their negative effect on wage levels of high school graduates, both young and old, and positive effects on wages of college

12 All monetary variables are in real terms. They are deflated by the Consumer Price Index.

13 According to the literature (BLS Bull, 1989), the same lag holds for the effects of R \& D on productivity growth. 
graduates. Specifically, equations (1) and (2) of Table 3 show a negative effect of the Jorgenson productivity growth index (PG) on wage levels of young and of older college graduates, but a positive effect on wages of young college graduates, and no significant effect on wages of older college graduates. Equation (3) and (4) shows a negative effect of the research and development variable ( $\&$ \&) on wages of young and older high school graduates, but a positive effect on wages of college graduates at both levels of experience.

The international trade deficit (RNE) reduced wages of young high school graduates, but not of older ones, and had a weak, but if anything, an opposite effect on wage levels of college graduates. Finally, the ratio of service to goods employment (RSG) had a negative effect on wages of young, and less so of older high school graduates and a positive effect on wages of young (less clearly), and of old college graduates (more clearly).

As was expected, the RNE and RSG variables tend to substitute for one another, so their effects are attenuated when both are included in the regressions (2) and (4) of Table 3.

\section{Experience Wage Premia: Age Differentials in Wages}

The cross-sectional experience wage profile reflects (working) age differentials in wages. In a large literature, growth of older to younger wage ratios between the 1960's and 1970 's has been attributed to the entry of the baby boom cohorts into the labor market. ${ }^{14}$ With increased supplies of young workers relative to older workers, relative wages for the young declined, steepening the wage profiles in all education groups. Relative supplies (ratio of numbers of younger to all workers in the education group) were shown in Fig. 4. Until the mid 70's relative growth in young cohorts characterized all education groups, but was especially pronounced for post-secondary graduates. As a result Fig. 2 shows that (log) wage ratios of older (those with 21-25 years of experience) to younger workers (with 1-5

14 See Welch $(\$ 7 y)$ and the references therein. 
years of experience) increased, more steeply for college than for high school graduates. Subsequently, however, the relative supply of young college graduates declined almost as steeply as it rose before, while the proportion of young high school graduates entering the market continued to increase until the mid eighties. Fig. 2 shows a continued steepening of the HS wage profile, accelerated in the 1980's. In contrast, the college wage profile stabilizes in the 70's and 80's. While the difference between the two education age profiles of wages is to some extent consistent with the differential growth of relative numbers, we might have expected a flattening of the college profile, given the relative decline in its young cohorts. The much steeper growth of the high school wage profile in the 80 's than in the 70's is also out of line with the milder (compared to the college profile) and not accelerating increase in relative numbers of young high school graduates.

Additional factors must have been at play in preventing the college profile from flattening and in accelerating the growth of the high school profile in the 1980's. A growing demand for skilled and experience workers and a declining demand for unskilled and inexperienced workers would be consistent with the data in the face of the fading and reversal of the "baby boom."

A cursory look at differential effects of the demand variable (R \& D, PG, RSG, and RNE) on levels of wages in Table 3 shows consistently stronger effects on wages of younger then older high school graduates. This is clear in the negative effects of high school wages and less clearly in positive effects on college wages. The relative skill bias of demand for labor thus contributes to the understanding of the differential changes in the slopes of wage profiles in the high school and college groups.

A hypothesis which interprets these findings is that the changing profitability of human capital is reflected in age differentials in wages which are due to acquisitions of human capital at work, as it was in educational differentials resulting from differences in 
human capital acquired at school. Although relative supply factors differ by school and age, the same demand factors must be at work. This hypothesis permits two alternative specifications of the wage profile regressions in Table 4. One, shown in col. 1 of Table 4 is to include, in addition to the cohort variable of the education group, the demand variables which were utilized in the educational premia regressions in Table 2. Alternatively, as shown in col. 2 and 3 of Table 4, the profitability variable itself (or its estimated value by the Table 2 regressions) can be used for the same purpose.

Wage disadvantages for younger workers and wage advantages for older cohorts steepen the profile. Among the disadvantages of younger workers are the growth of their cohort in the education group (variable DRE), growth of net imports for the less educated, especially younger workers (RNE), and business cycle declines which tend to affect the young, low-tenured workers disproportionately, here measured by the unemployment rate (u). Relative wage advantages accruing to experienced (older) workers in both education groups are captured by the research and development (R \& D) variable. All these variables were included in eq. (1).

As (col. 1) in Table 4 shows, each of the variables is significant ${ }^{15}$ in explaining the changing wage profile of high school graduates of the past 25 years. Jointly they explain $92 \%$ of the time variance of the wage profile. The college profile is not significantly affected by the international trade variable, as would be expected, and the joint explanatory power of the regression is correspondingly weaker than in the high school group. Here $\mathrm{R}^{2}$ $=.78$.

The wage profiles predicted by these regressions are indicated by broken lines in Fig. 11 and 12, for high school and college respectively.

15 The (PG) and (RSG) variables were not significant. Neither was a capacity utilization variable when substituted for the unemployment rate. 
In the alternative specification (col 2 and 3 of Table 4) the educational wage premium is substituted for the demand variables of col. 1. The reasoning, spelled out before, was that, if human capital becomes more profitable, both educational and experience wage premia should increase.

The estimated value of the college wage premium, based on eq. 3 of Table 2 and shown in the broken line of Fig. 10, has a stronger effect on the wage profiles of high school graduates than on that of college graduates. Also, equation 2 which uses the estimated college premium in the high school wage profile regression yields an $\mathrm{R}^{2}=.88$, close to the explanatory power of eq. (1).

The explanatory power of the college-high school wage premium in the college wage profile regression is much lower $\left(\mathrm{R}^{2}=.50\right.$ in col. 2$)$. Although the profitability of experience moves in the same direction as the profitability of education, changes in the wage profile of the lower education group appear to be more closely tied to changes in profitability of the higher education group, rather than conversely. This impression is strengthened when the use of the post-graduate wage premium (relative to college) in the college experience regression yields a stronger explanatory power $\left(\mathrm{R}^{2}=.65\right.$ compared to .50 in col. 3) for college; while the high school educational premium (relative to drop outs) yields only a weak effect in the high school regression, (with $\mathrm{R}^{2}=.75$ compared to .88 in col. 3).

Since the college premium was estimated by regression, while the high school (relative to dropouts) and postgraduate (relative to graduate) premium are observed values (not regression estimated), the comparisons may be misleading. Table 5 therefore shows these comparisons in terms of observed premia: Here WRAT (A) is the premium relative to the next higher educational group, WRAT (B) is relative to the next lower. The results for the high school profile are confirmed: It is the rise in the college premium WRAT (A) 
that makes experience of high school more valuable, rather than the high school premium WRAT (B): The latter is smaller, and barely significant. At the college level, the effects (in terms of regression coefficients) appear to be equal for WRAT (B) and WRAT (A), though the explanatory power is greater for the latter. Finally, the slope of the high school dropout group (8-11) shows no effects of educational premia below or above, while the educational premium WRAT (B), (the only possible) is positive and significant for the slope of the postgraduate group.

In sum, a growing educational premium (best visible in the college-high school differential) raises the slopes of all education groups, high school and above. ${ }^{16}$ The effects are on balance, stronger when the profitability of the next higher groups changes. It is difficult, however, to say, at this point, whether this means that on the job skills of high school graduates rather than of college graduates substitute more for the scarcity of numbers of college graduates.

A somewhat better insight into this question may be gotten by looking at progress over time rather than cross-sections. This is done for groups of young workers in Table 6. Here the dependent variable is growth of wages over 3 successive calendar years ${ }^{17}$ of experience for the young workers (experience 3-6 and 7-10 pooled). The regression shows a positive effect of the college premium on progress of young high school workers, but not on early growth of college graduates wages. This is somewhat clearer evidence that skill training of young high school graduates responds (at least in profitability terms) to the demand for or scarcity of college skills.

Table 6 also indicates a negative cohort effect on wage progress as distinguished from cross-sectional slope, in the college group. No effect is seen in the high school group.

16 With the exception of "some college."

17

Given experience level $x$ in year $t$, we look at wages of $(x+1)$ in year $(t+1)$, and so on. 
If training effects on wages are reflected in the longitudinal findings, the results appear to indicate that effects of changes in the age distribution (teacher-trainee ratios) rather than of changes in opportunity costs affected changes in the profitability of training. This suggests that the larger cohorts of college graduates in the 70's received less (or less profitable) training than before, when their numbers were larger than in the 80 's when they became scarce. Training of high school graduates, by the same interpretation, declined or became less profitable in the 70's not because of the cohort increase (which was mild), but because of the abundance of college graduates (as reflected in the low college wage premium). A reversal in the 80 's results, therefore, from the newly emerging scarcity of college graduates.

We may infer from this interpretation that job training is likely to have become more profitable in the 1980's compared to the 1970's, for both college and high school graduates. ${ }^{18}$

\section{SUMMARY AND CONCLUDING REMARKS}

The empirical analysis resulted in several findings:

1. The year-to-year educational wage differentials (between college and high school) are very closely tracked by relative supplies of graduates in (roughly) their first decade of work experience, and by changes in relative demand for more educated workers which is indexed by research and development expenditures per worker (RDE), as well as by relative trends in service employment (RSG). Of these, RDE accounts for most of the explanatory power. Both Jorgenson type multifactor productivity growth (PG) indexes and net growth of goods imports were significant as alternatives, but showed weaker explanatory power.

18 Scattered evidence on profitability of job training (Mincer, 1989) yields no clear evidence on this inference. 
2. With the decline of average productivity growth and the near-cessation of average real wage growth, the skill-biased changes in demand took the form of increases in demand for workers with post-secondary education and decreases in demand for workers at lower education levels.

3. Changes in age distributions (cohort effects) account, in part, for the observed steepening of experience profiles of wages. They do not account for the acceleration of the high school profile or for the stabilization of the college profile between the 1970's and 1980's. An explanation is provided by additional variables reflecting the growing profitability of human capital which extends to that acquired by experience on the job. This is shown by the effects of the demand factors which are both skill and age biased, or alternatively by the effects of changing profitability (educational wage differentials) which is due to the demand changes, given the relative demographic supplies

In the latter specification, it appears that the increased value of experience of high school graduates is related to growing profitability of additional (college) education, but not of its own (relative to high school dropouts). Also, the increased value of experience of college graduates is related both to the profitability of college and of post-graduate education.

Viewed longitudinally, some evidence confirms the positive effect of profitability of college on wage growth of young high school graduates, but not on the profile of college graduates. Also, negative cohort effects are observed on wage growth of college graduates but none on high school graduates. This limited evidence may suggest substitution between (college) school education and work experience or training of high school graduates. It also suggests that large cohorts reduce, rather than increase the profitability of training by increasing, rather than reducing its costs. 
Increased growth in college enrollments of high school graduates which started in the 1980's may continue in the 1990's if the rates of return have not yet stabilized. We should note that these increases do not translate into absolute numbers, as the young cohorts declined. Growth of job training is all the more predictable, short of a protracted recession, or of prohibitive costs due to a deteriorating quality of trainees.

The major purpose of this study was to detect effects of changes in technology on changes in the demand for human capital. Positive effects of the pace of technology have been observed before in decade-long cross-sections across industrial sectors. The present study extends the analysis to annual time series at the national, aggregate level. It explores alternative empirical indexes of the pace of technology. Effects of changes in demand for human capital are observed in regressions, in which the dependent variables are the profitability of human capital acquired at school, measured by the educational wage differential, and on human capital acquired at work, measured by the experience wage differential. In order to observe these effects, it was necessary to include in the analysis other factors affecting the profitability of human capital, such as relative educational composition and age distributions, representing educational and experience dimensions of relative supplies of human capital. As a result, this study joins a number of recent studies which analyze the changing wage structure in recent decades.

The implementation of empirical indexes or proxies for the changing pace of technology appears to be successful in verifying its role in affecting the demand for human capital, and the direction of its skill bias. These findings move us closer to an understanding of the apparent paradox of an absence of long term decline in the profitability of human capital despite the massive growth of educational attainment. It remains to be seen whether the positive skill bias of technology inferred for the past 2-3 decades dominated also the preceding economic history. 
Shorter-term (decade long?) fluctuations in the profitability of human capital, here seen as skill differentials in wages, generate supply (enrollment) responses which, over time, provide a corrective to changes in profitability in an equilibrating manner. The long term tendencies toward equilibrium are apparently trendless. I do not analyze the supply response. Rather, it is its feedback effect through a long pipeline - that shows up in effects on profitability in this study.

The supply responses, or change in enrollment, are sensitive both to returns and costs of educational investments. The latter include opportunity costs as well as net direct costs. Direct costs are a balance of tuition and fees and of student earnings, loan subsidies, and grants. Skill (education) differentials in wages analyzed here (and elsewhere) measure returns net of opportunity costs only. They, therefore, overstate the growth of profitability, if net direct costs increase. It is very likely that the decline of profitability of human capital in the 70's, and even more so its rebound in the 80's are somewhat overstated. The overstatement is not major, as private net direct costs are much smaller than foregone earnings at the post-secondary levels.

Fluctuations in the indexes of technology rule out assumptions of a steady pace of demand for human capital. The reality behind the turn around in the "pace of technology" indexes between the 1970's and 1980's may be attributed to a growing momentum in information technologies. Indeed, supply responses in particular fields currently visible at the post-graduate level, support this view: The U.S. Department of Education (OERI, 1990) reports that the number of MA's conferred in mathematics, computer science and engineering grew $70 \%$ in the 1980 's, while stagnant in other fields (with the exception of MBA's who grew 25\%). Among doctoral degrees which grew 7\% since 1980, engineering degrees which declined in the 1970 's, grew $67 \%$ in the 1980 's. Similarly, the number of doctorates in the natural sciences, which declines sharply in the 1970's, has outpaced the growth of total doctorates since the early 1980 's. 
A great deal of apprehension has been generated by the perception of a deteriorating quality of high school and lower levels of education in the past two decades. Evidence of low achievement levels is found in SAT scores, and more compellingly in international comparisons according to which, U.S. students (high school and below) are in bottom ranks among industrialized countries. Deterioration over time is more difficult to document. Some weak evidence consists of declines in SAT scores, which levelled off recently and increases in GED, high school equivalence certificates, relative to high school graduation. If quality deterioration has not (yet?) affected post-secondary education, it may have contributed to the widened educational wage differential. If so, this is another reason for a likely overstatement of the recent growth in profitability of college education. 
Bartel, A and F. Lichtenberg, The Comparative Advantage of Educated Workers in Implementing New Technology," The Review of Economics and Statistics, February 1987.

Blackburn, M. L, D. E. Bloom, and R. B. Freeman, The Declining Economic Position of Less Skilled American Men," in A Future of Lousy Jobs?, G. Burtless, editor, The Brookings Institution, 1990.

Becker, G. S., Human Capital, 2nd ed., Chicago University Press, 1975.

Berger, M. C., The Effect of Cohort Size on Earnings Growth," Joumal of Political Economy, June 1985.

U.S.D.O.L, Burcau of Labor Statistics, The Impact of Research and Development on Productivity Growth, Bulletin 2331, September 1989.

Cyert, R. M. and D. C. Mowery, Technolesy and Employment, National Academy Press, Washington, D.C., 1987.

Freeman, R. B., The Overeducated American, Academic Press, 1976.

"Demand for Education," Ch. 6 in Handbook of Labor Economics, vol. 1, $O$. Ashenfelter and R. Layard, eds., North-Holland, 1986.

Gill, I., Technological Change, Education, and Obsolescence of Human Capital, " Ph.D. Thesis, University of Chicago, 1989.

Griliches, Z., "Capital-Skill Complementarity," The Review of Economics and Statistics, November 1969.

Hamermesh, D. and J. Grant, "Econometric Studies of Labor - Labor Substitution and Their Implications for Policy," Journal of Human Resources, Summer 1979.

Jorgenson, D., F. Gollop, and B. Fraumeni, Productivity and U.S. Economic Growth, Harvard University Press, 1987. Updated series, 1990.

Kosters, M. "The Wage Structure," paper presented at American Enterprise_Institute Conference, September 1989.

Mincer, J., Schooling. Experience and Earnings, Columbia University Press, 1974.

Mincer, J., "Human Capital Responses to Technological Change," NBER Working Paper, December 1989.

Mincer, J., "Job Training, Costs, Returns, and Wage Profiles, "NCEE Paper, October 1989.

Mincer, J., and Higuchi, Y., "Wage Structures and Labor Turnover in the U.S. and in Japan," Journal of the Japanese and International Economics, June 1988.

Murphy, K., and F. Welch, "Wage Premiums for College Graduates," Educational Researcher, May 1989. 
Psacharopoulos, G., "Returns to Education: An International Update," Journal of Human Resources, Fall 1985 .

U.S. Department of Education, Office of Educational Research and Improvement, Conditions of Education, NCES Report 681, 1990.

Welch, F., "Effects of Cohort Size on Earnings," Journal of Political Economy, October 1979. 
TABLE 1

DESCRIPTIVE STATISTICS

VARIAEL
WRAT
DIFS1H
DIFS1C
LNVYH
LNUOH
LNWYC
LNWOC
W3GH
U3GC
RESH
RESC
DREH
DREC
DR
PG
RDE
RNE
RSG
U

LABEL

MEAN

STANDARD

DEVIATION

RATIO OF C TO HS WAGES

RATIO OF WAGES OF OLDER TO YOUNG FOR H

RATIO OF WAGES OF OLDER TO YOUNG FOR C LOG WAGES OF YOUNG HS GRADUATES

LOG WAGES OF OLDER HS GRADUATES

LOG WAGES OF YOUNG $C$ GRADUATES

LOG WAGES OF OLDER C GRADUATES

3-YEAR WAGE GROWTH, YOUNG HS

3-YEAR WAGE GROWTH, YOUNG C

RATIO OF YNG HS GRADS TO TOT YNG POP

RATIO OF YNG C GRADS TO TOT YNG POP

RATIO OF YNG HS GRADS TO TOT HS GRADS

RATIO OF YNG C GRADS TO TOT C GRADS

RATIO OF YOUNG TO TOTAL POPULATION

TOTAL FACTOR PRODUCTIVITY GROWTH

EXPENDITURES ON R\&D PER EMPLOYEE

RATIO OF NET EXPORTS TO GNP

RATIO \# EMP IN SERV. TO GDS. INDUSTRIES UNEMPLOYMENT RATE

0.06999860

0.54800320

0.59032320

2.01743201

2.49255201

2.31450881

2.87666801

0.03635897

0.04634133

$-0.91222274$

$-2.21722164$

$-1.13805892$

$-1.09088485$

$-1.18834869$

0.00590400

771.95500867

$-0.75736937$

2.30888321

5.07600000
0.01798548

0.09016164

0.08030222

0.11487096

0.06197540

0.06279818

0.07994201

0.02312090

0.02717765

0.03952945

0.16753791

0.07222434

0.15067780

0.10927553

0.00913302

70.29096926

1.33917798

0.43775142

1.73259920

NOTE. ALL RATIOS EXPRESSED AS DIFFERENCES IN LOGARITHMS 
TABLE 2

\section{Educational Wage Differentials}

$$
\text { (College - High School) }
$$

\begin{tabular}{|c|c|c|c|}
\hline \multirow[b]{2}{*}{ Variables } & \multicolumn{3}{|c|}{ Coefficients } \\
\hline & (1) & (2) & $(3)$ \\
\hline Intercept & $\begin{array}{l}-.09 \\
(1.4)\end{array}$ & $\begin{array}{l}-.59 \\
(3.4)\end{array}$ & $\begin{array}{l}-.41 \\
(4.6)\end{array}$ \\
\hline RESY $_{-2}$ & $\begin{array}{r}-.065 \\
(2.2)\end{array}$ & & \\
\hline REST $_{-3}$ & & $\begin{array}{l}-.086 \\
(1.9)\end{array}$ & $\begin{array}{l}-.080 \\
(3.0)\end{array}$ \\
\hline $\mathrm{DR}-2$ & & $\begin{array}{l}-.20 \\
(4.6)\end{array}$ & \\
\hline PG & $\begin{array}{l}1.12 \\
(2.2)\end{array}$ & $\begin{array}{l}.45 \\
(1.00)\end{array}$ & \\
\hline$R \& D_{-2}$ & & & $\begin{array}{l}.00024 \\
(12.3)\end{array}$ \\
\hline RNE & $\begin{array}{l}-.011 \\
(4.5)\end{array}$ & & \\
\hline RSG & & $\begin{array}{l}.088 \\
14.1\end{array}$ & $\begin{array}{l}.044 \\
(3.5)\end{array}$ \\
\hline $\mathrm{R}^{2}$ & .69 & .80 & .91 \\
\hline
\end{tabular}

$t$ - values in parentheses. Excluded variables not significant. subscripts -2 and -3 denote a 2 -year and 3 -year lag. 


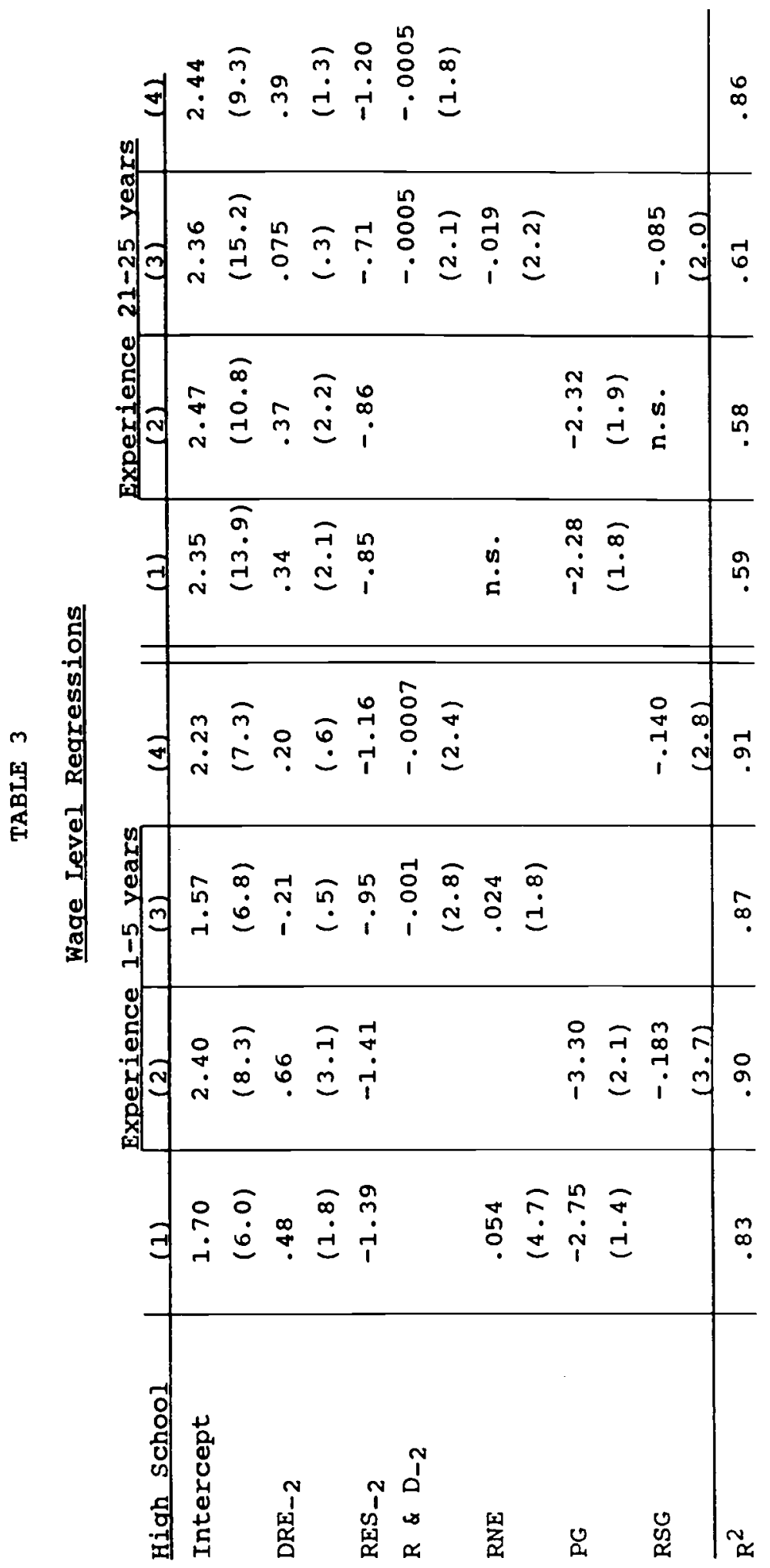




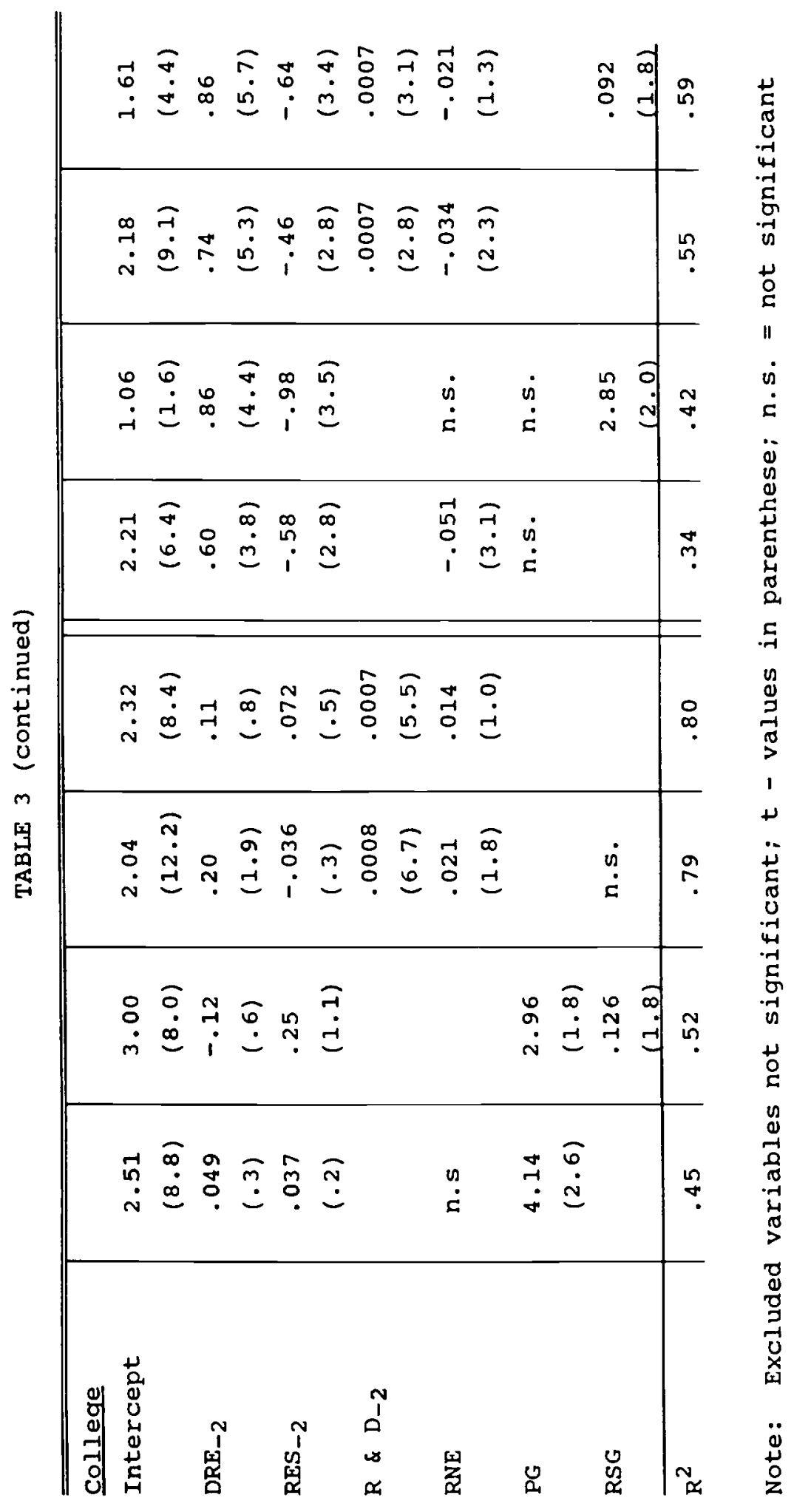




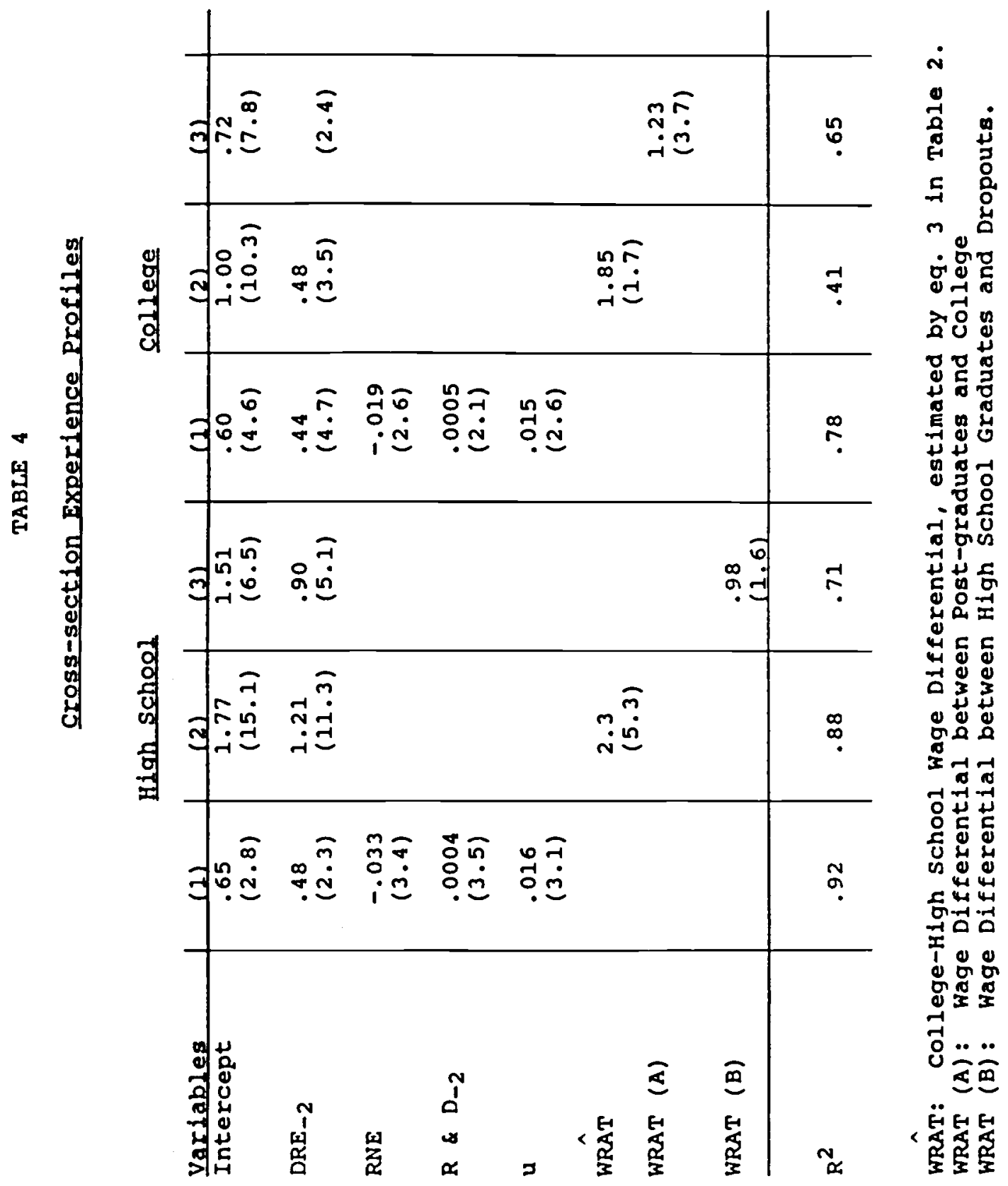




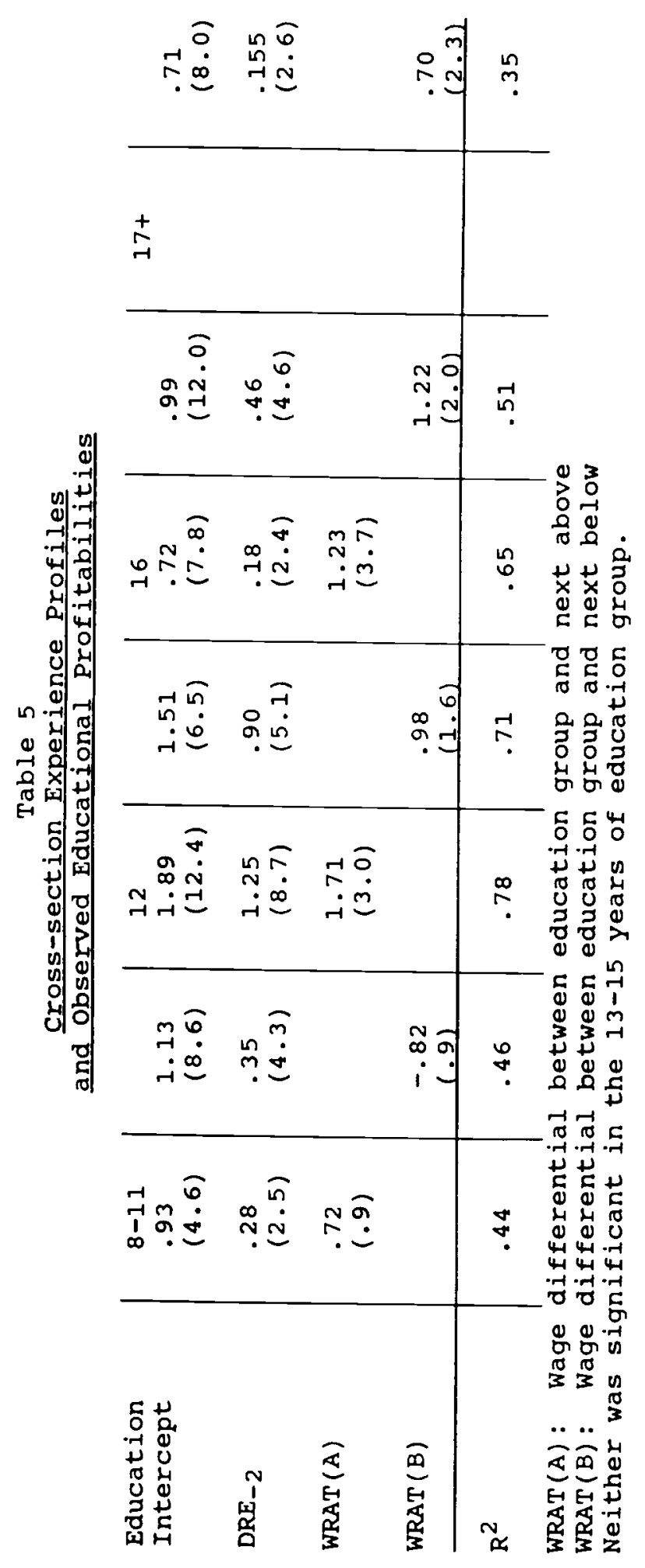


Table 6

Wage Growth of Young Workers

over 3 years of Calendar Time

\begin{tabular}{l|c|c} 
& High School & College \\
\hline \multirow{2}{*}{ Intercept } & -.054 & -.060 \\
& $(.9)$ & $(3.4)$ \\
DRE-2 & -.028 & -.144 \\
& $(.4)$ & $(5.5)$ \\
WRAT(A) & .77 & \\
WRAT (B) & $(2.9)$ & \\
& & $(3.4)$ \\
$\mathrm{R}^{2}$ & .49 & .64
\end{tabular}




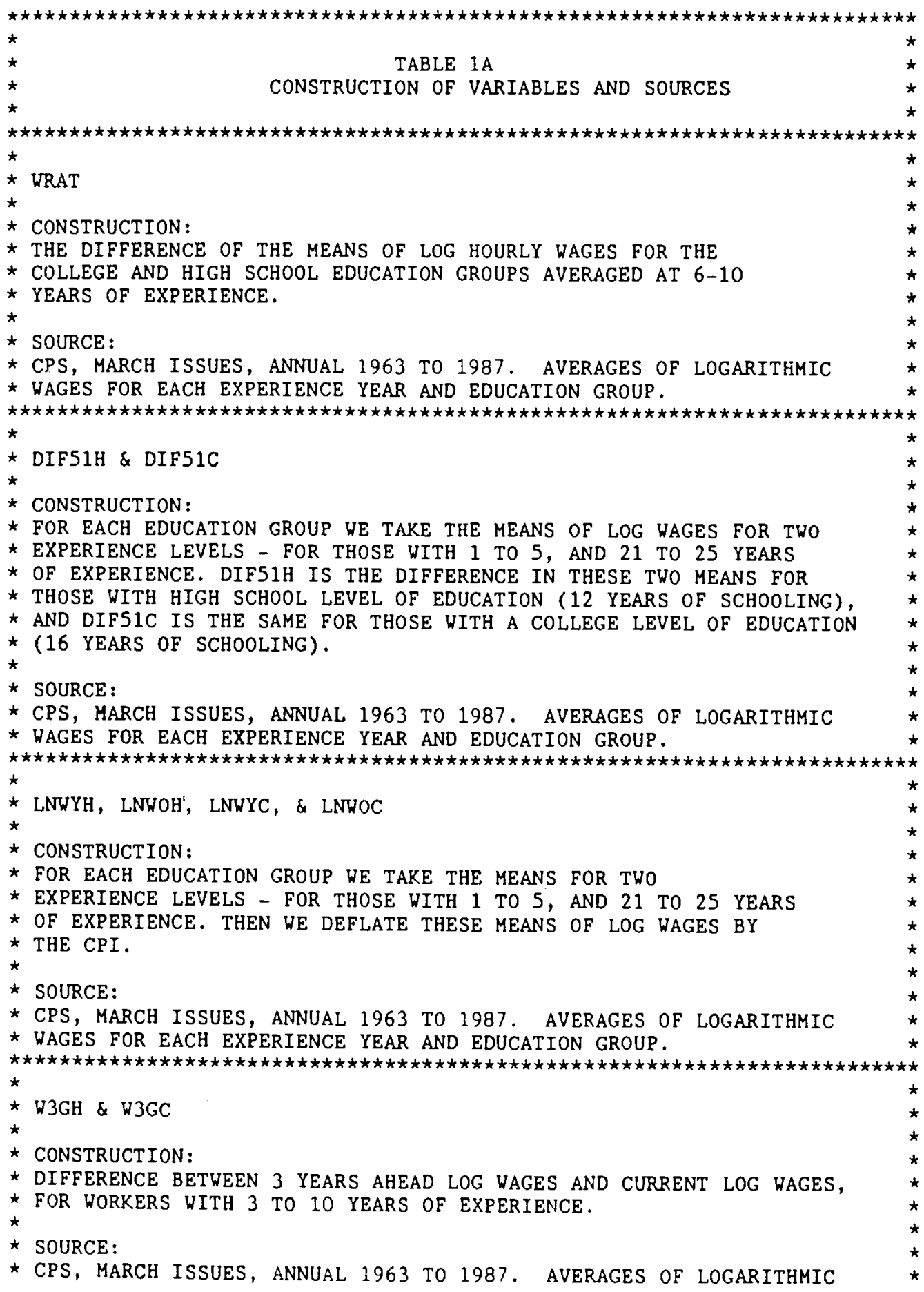


* VAGES FOR EACH F.XPERIENCE YEAR AND EDUCATION GROUP.

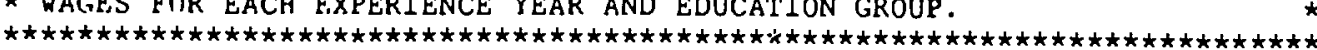

* RESH, RESC, DREH, DREC, \& DR

$\star$

* CONSTRUCTION:

* RESH=LOG (\# OF NONINSTITUTIONAL POPULATION IN THE AGE GROUP OF 20-29

* YEARS WITH HIGH SCHOOL DIPLOMA (12 YEARS OF SCHOOLING)/

* TOTAL \# OF NONINSTITUTIONAL POPULATION IN THE AGE GROUP OF 20-29\}.

* RESC=LOG ( \# OF NONINSTITUTIONAL POPULATION IN THE AGE GROUP OF 20-29

* YEARS VITH COLLEGE DEGREE (16 YEARS OF SCEOOLING)/

* TOTAL \# OF NONINSTITUTIONAL POPULATION IN THE AGE GROUP OF 20-29\}.

$\star$

* DREH=LOG (\# OF NONINSTITUTIONAL POPULATION IN THE AGE GROUP OF 20-29

* YEARS VITH HIGH SCHOOL DIPLOMA (12 YEARS OF SCHOOLING)/

* TOTAL \# OF NONINSTITUTIONAL POPULATION (AGE GROUP OF 18-64) WITH

* HIGH SCHOOL DIPLOMA (12 YEARS OF SCHOOLING)).

$\star$

* DREC=LOG (\# OF NONINSTITUTIONAL POPULATION IN THE AGE GROUP OF 20-29

* YEARS WITH COLLEGE DEGREE (16 YEARS OF SCHOOLING)/

* TOTAL \# OF NONINSTITUTIONAL POPULATION (AGE GROUP OF 18-64) WITH

* COLLEGE DEGREE ( 16 YEARS OF SCHOOLING)\}.

* DR=LOG $\{$ \# OF NONINSTITUTIONAL POPULATION IN THE AGE GROUP OF 20-29

* YEARS/TOTAL \# OF NONINSTITUTIONAL POPULATION (AGE GROUP OF 18-64)\}.

* SOURCE :

* U.S. bUREaU of the CENSUS. CURRENT POPUlation REPORT. P-20

* SERIES. EDUCATIONAL ATTAINMENT IN THE UNITED STATES. 1964-1988.

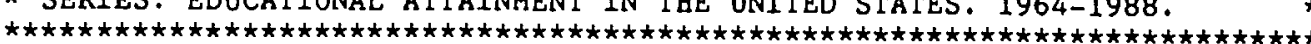

* PG

$\star$

$\star$ SOURCE :

* JORGENSON D., Gallop F., AND FRAUMENI B., PRODUCTIVITy AND U.S.

* ECONOMIC GROWTH, HARVARD UNIVERSITY PRESS, 1987. UPDATED SERIES, $\star 1990$.

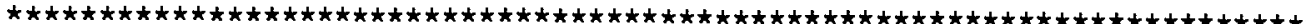

$\star$

$\star \mathrm{RDE}$

*

* CONSTRUCTION :

* RDE=TOTAL DOLLAR EXPENDITURE ON RESEARCH AND DEVELOPMENT DIVIDED

* BY THE TOTAL EMPLOYED IN THE U.S. LABOR FORCE.

$\star$

* SOURCES :

* (1) TOTAL EMPLOYED IN U.S. LABOR FORCE - ECONOMIC REPORT

* OF THE PRESIDENT, FEBRUARY 1990. TABLE C-33, PAGE 332.

* (2) R\&D EXPENDITURE IN PRIVATE SECTOR - THE IMPACT OF RESEARCH

* AND DEVELOPMENT ON PRODUCTIVITY GROWTH. U.S. DEPARTMENT OF LABOR.

* BUREAU OF LABOR STATISTICS. SEPTEMBER 1989. BULLETIN 2331

* TABLE-10. PAGE 26.

* (3) Rá EXPENDITURE IN GOVERNMENT SECTOR - BUDGET AUTHORITY DATA

* FROM THE NATIONAL SCIENCE FOUNDATION $(1985,1986 \mathrm{~B})$. PAGE 35 IN 
* TECHNOLOGY AND EMPLOYMENT -- INNOVATION AND GROWTH IN THE U.S.

$\star$ ECONOMY.

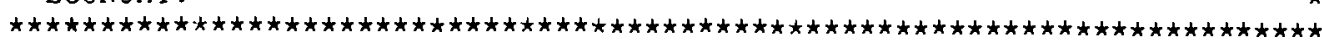

$\star$

$\star$ RNE

$\star$

* CONSTRUCTION :

* THE RATIO OF NET EXPORTS IN DOLLARS TO GNP IN DOLLARS

* MULTIPLIED BY 100, GENERATING THE PERCENT FIGURE OF NET EXPORTS TO

* GNP.

$\star$

* SOURCE:

* ECONOMIC REPORT OF THE PRESIDENT FEBRUARY 1990. NET EXPORTS-

$\star$ TABLE C-102, PAGE 410, COLUMN 3. GNP- TABLE C-10, PAGE 306, COLUMN 1. $\star$

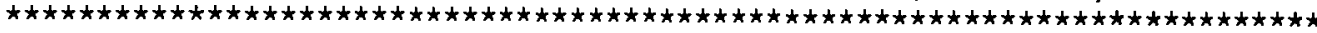

$\star$

$\star$ RSG

$\star$

* CONSTRUCTION:

* RATIO OF THE NUMBER EMPLOYEES IN GOODS-PRODUCING

* INDUSTRIES TO THE NUMBER OF TMPIOYEES IN SERVICE PRODUCING INDUSTRIES *

$\star$

$\star$ SOURCE :

* ECONOMIC REPORT OF THE PRESIDENT FEBRUARY 1990. TOTAL

* NUMBER OF EMPLOYEES IN GOODS-PRODUCING INDUSTRIES- TABLE C-43,

* PAGE 342 , COLUMN 2. NUMBER OF EMPLOYEES IN SERVICE-PRODUCING

* INDUSTRIES- TABLE C-43, PAGE 343, COLUMN 1 .

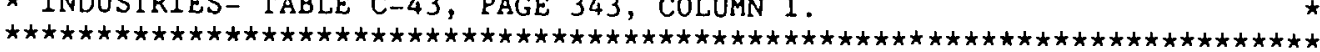

$\star$

$\star \mathrm{U}$

$\star$

* SOURCE:

* THE AGGREGATE UNEMPLOMENT RATE REPORTED IN THE ECONOMIC REPORT

$\star$ OF THE PRESIDENT FEBRUARY 1990. TABLE C-40, PAGE 339, COLUMN 3.

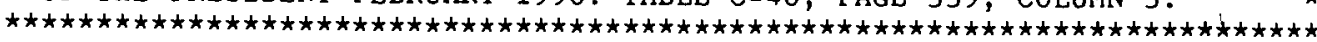




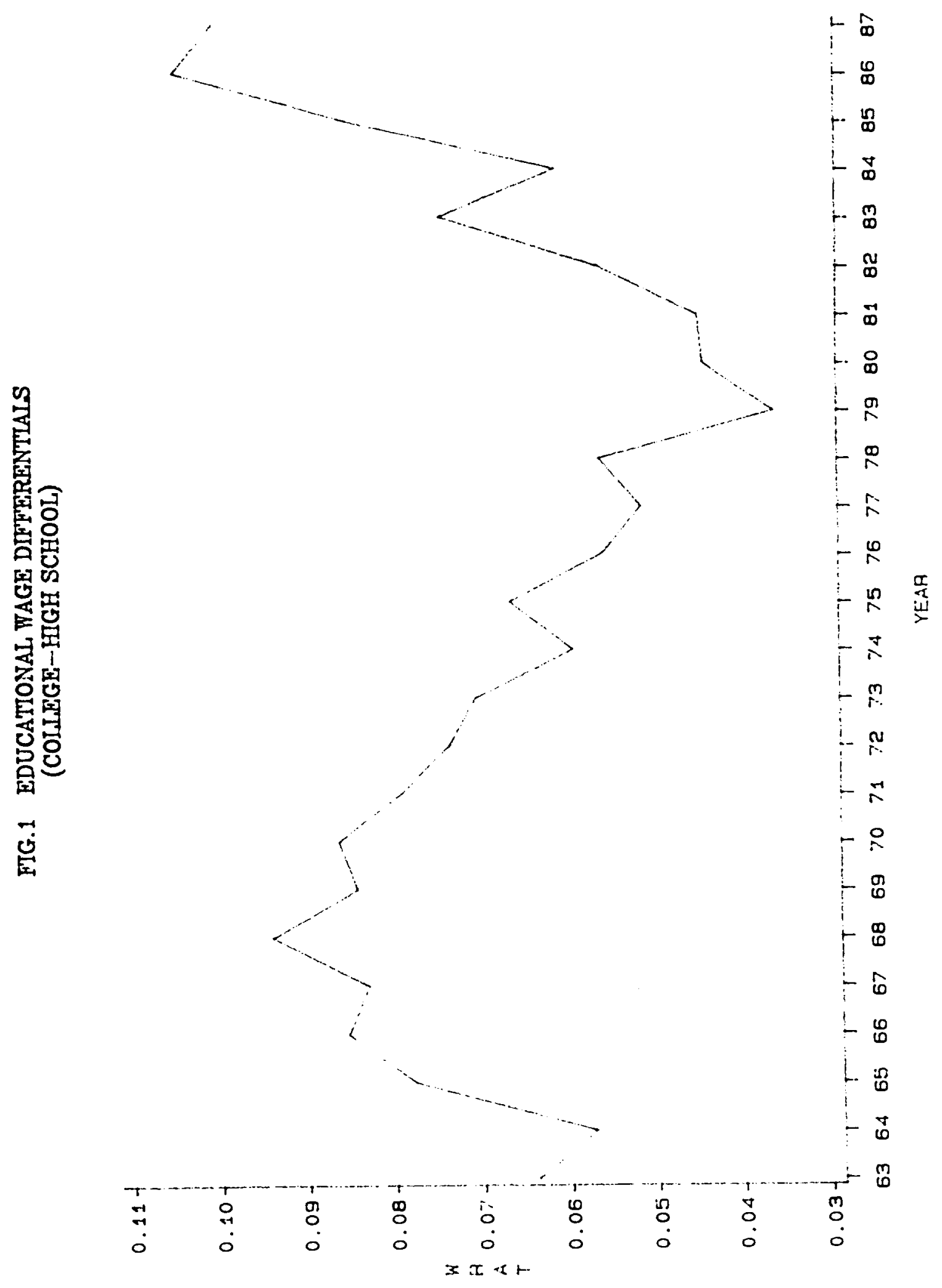



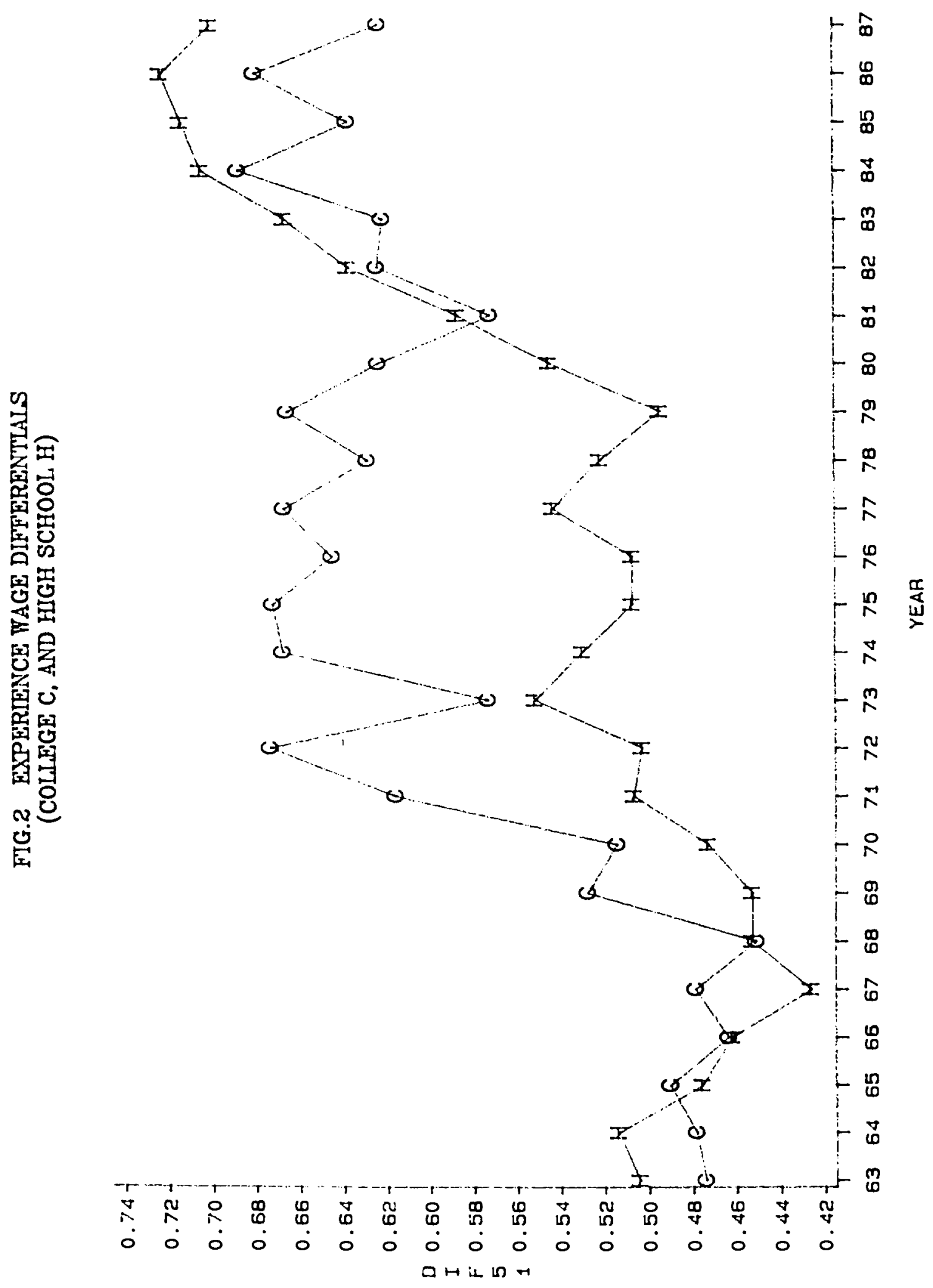


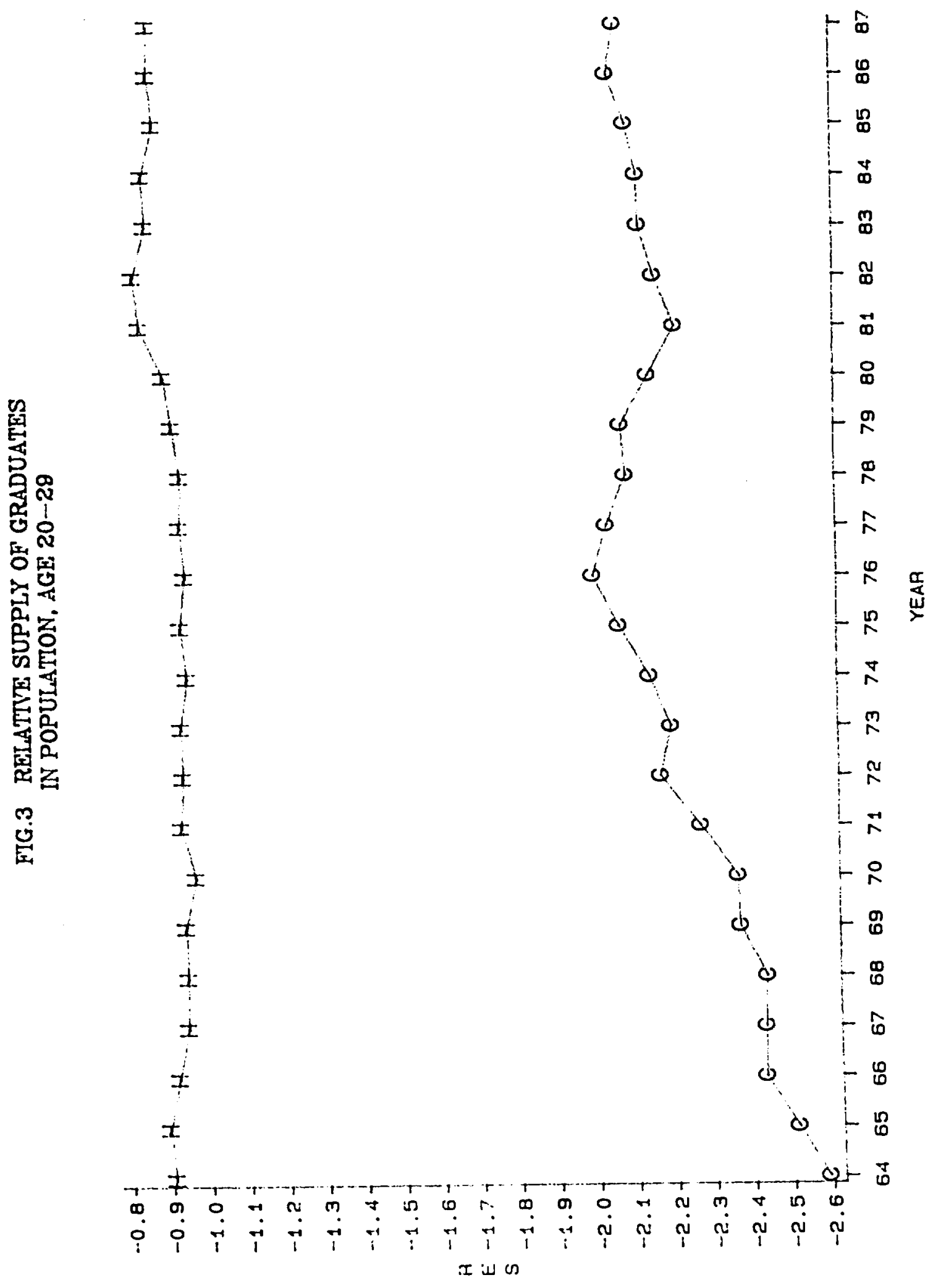




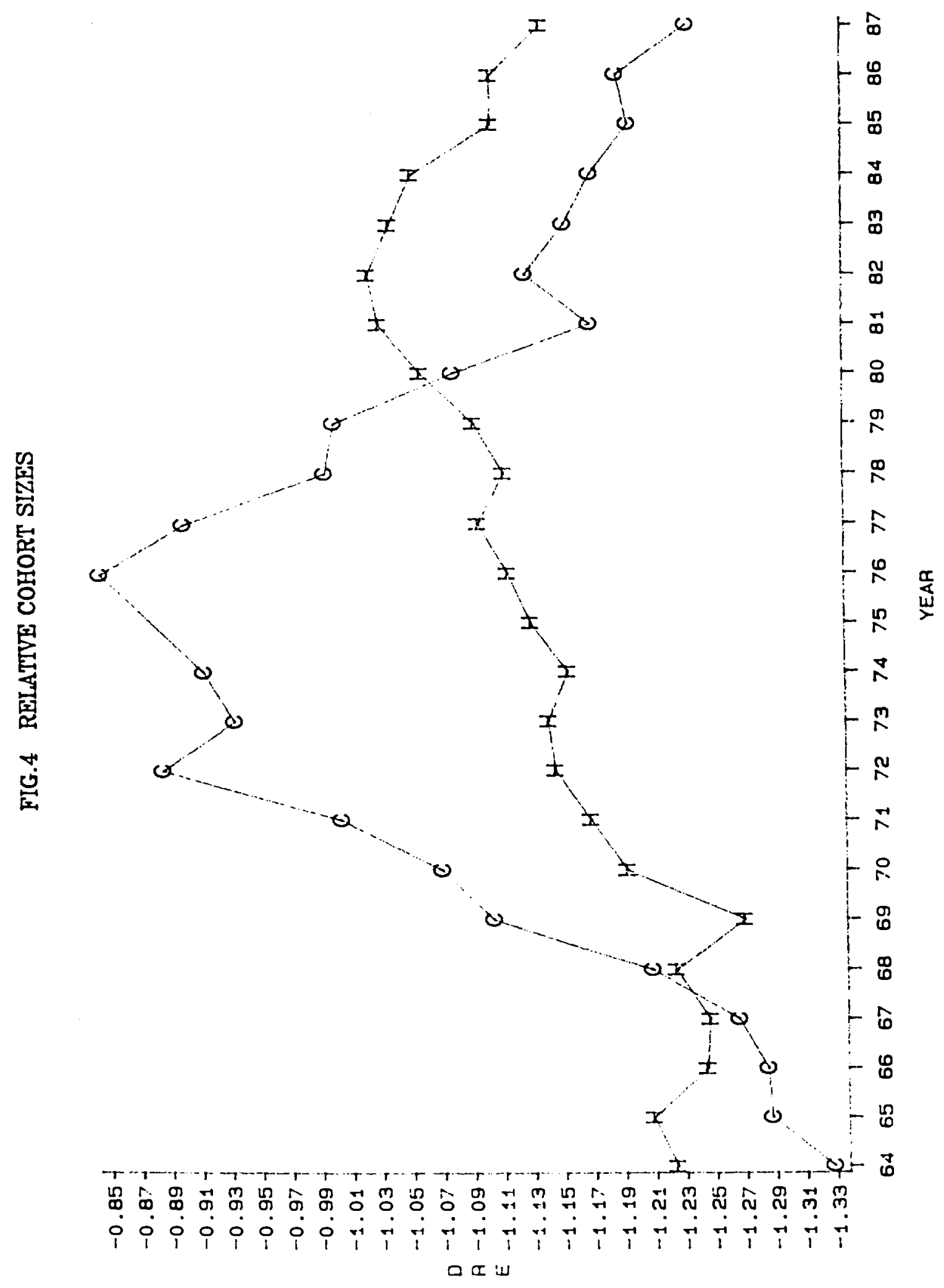




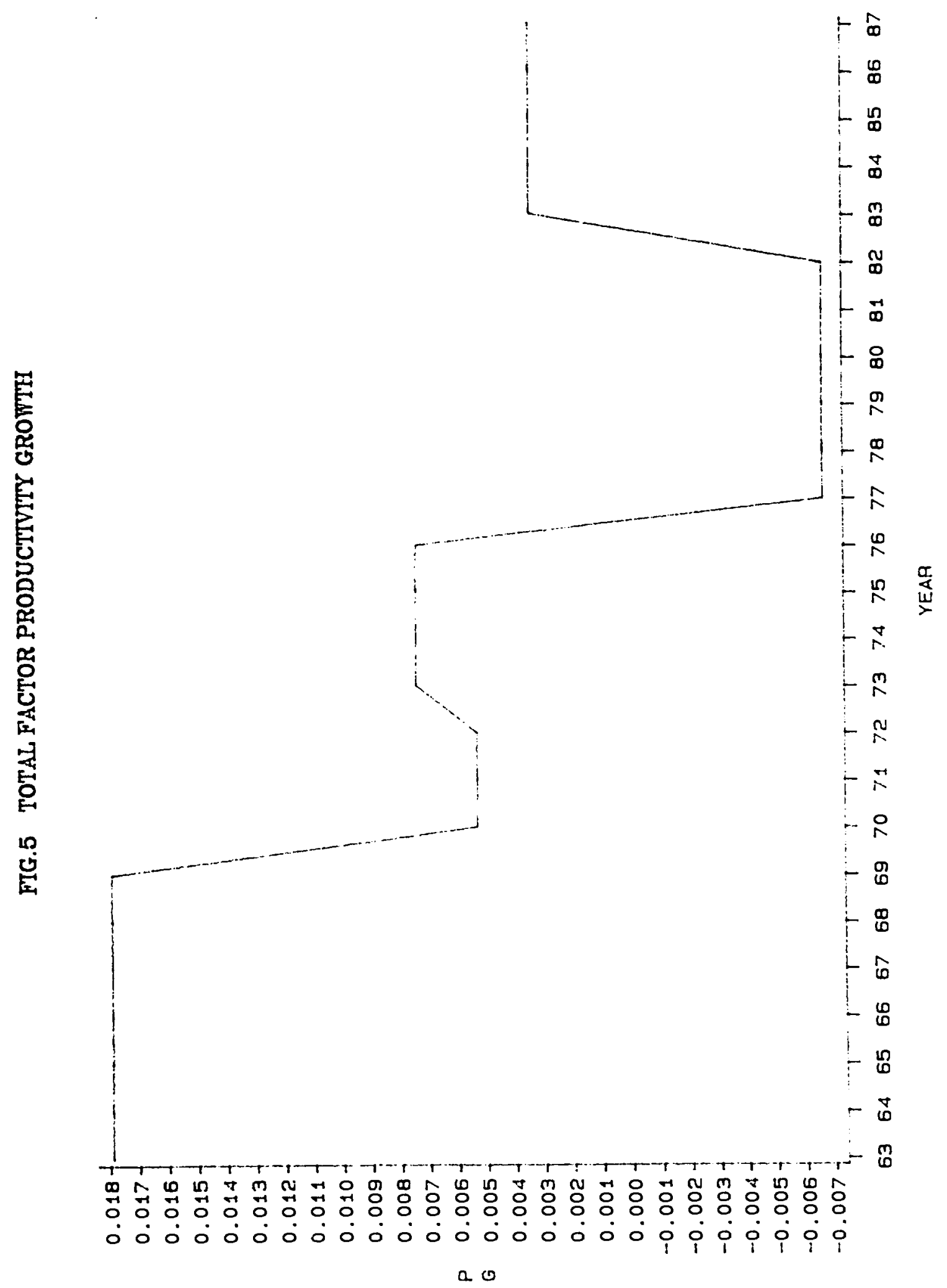




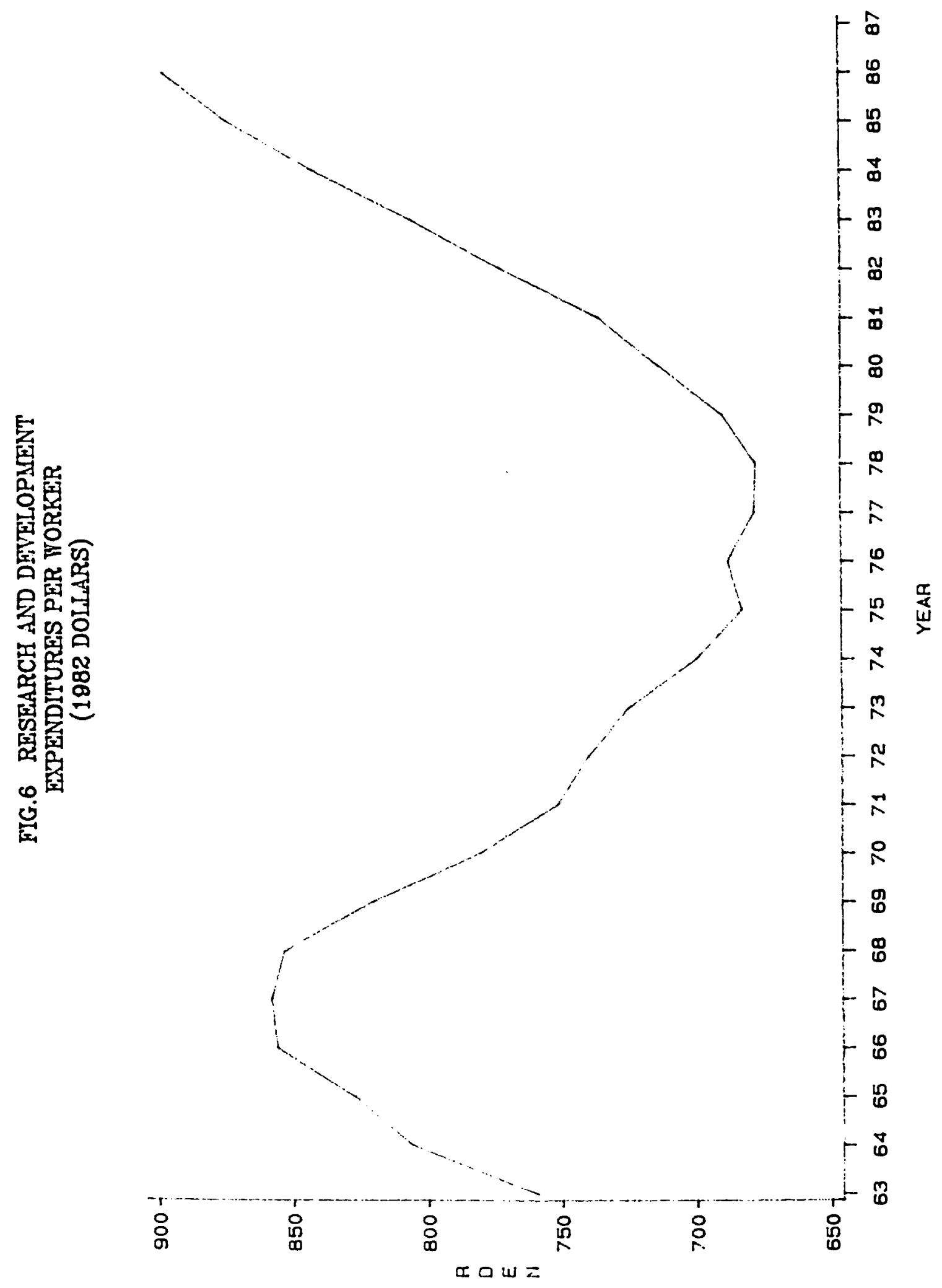



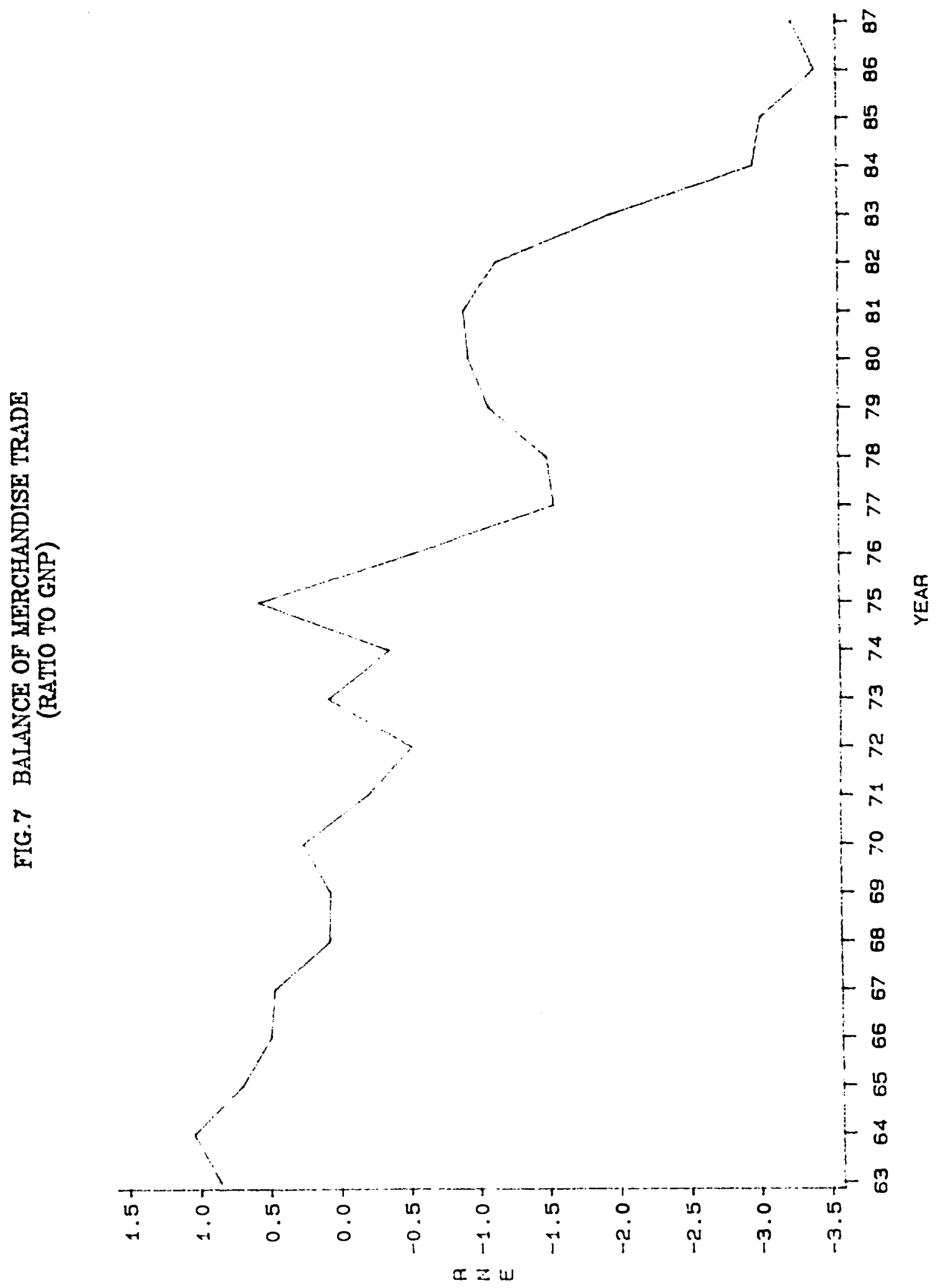


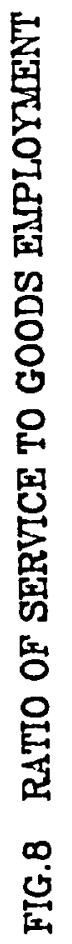

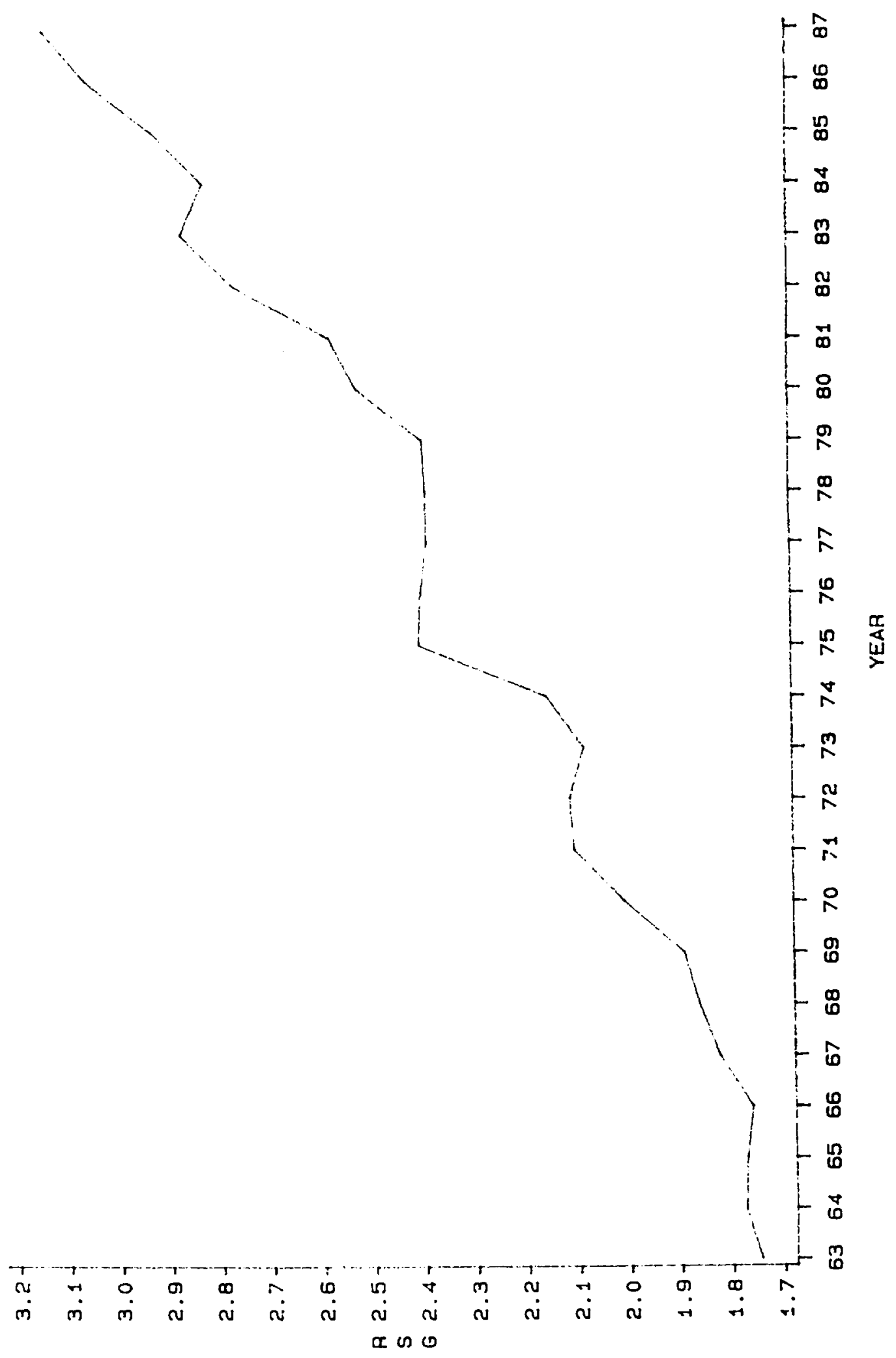




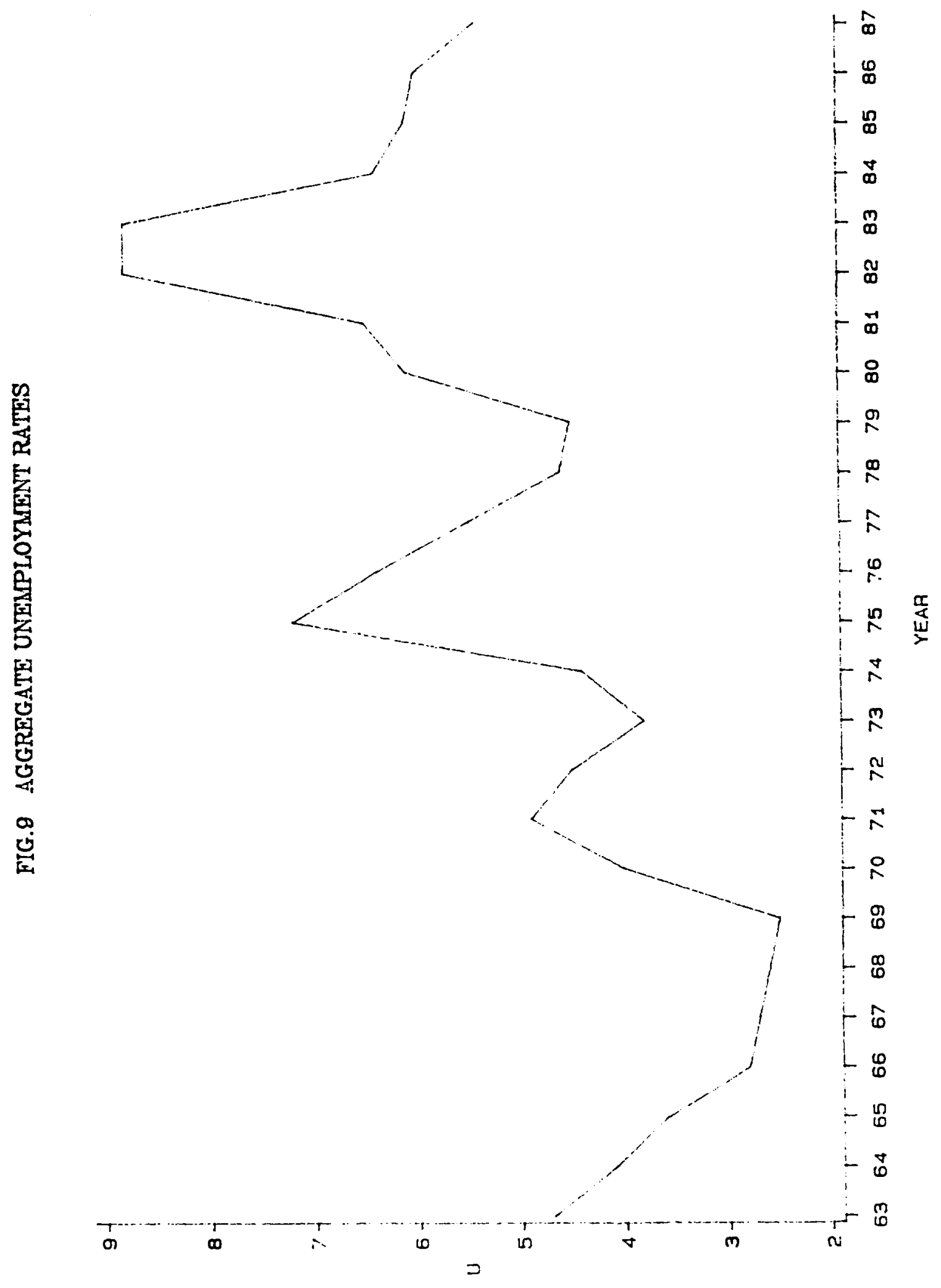



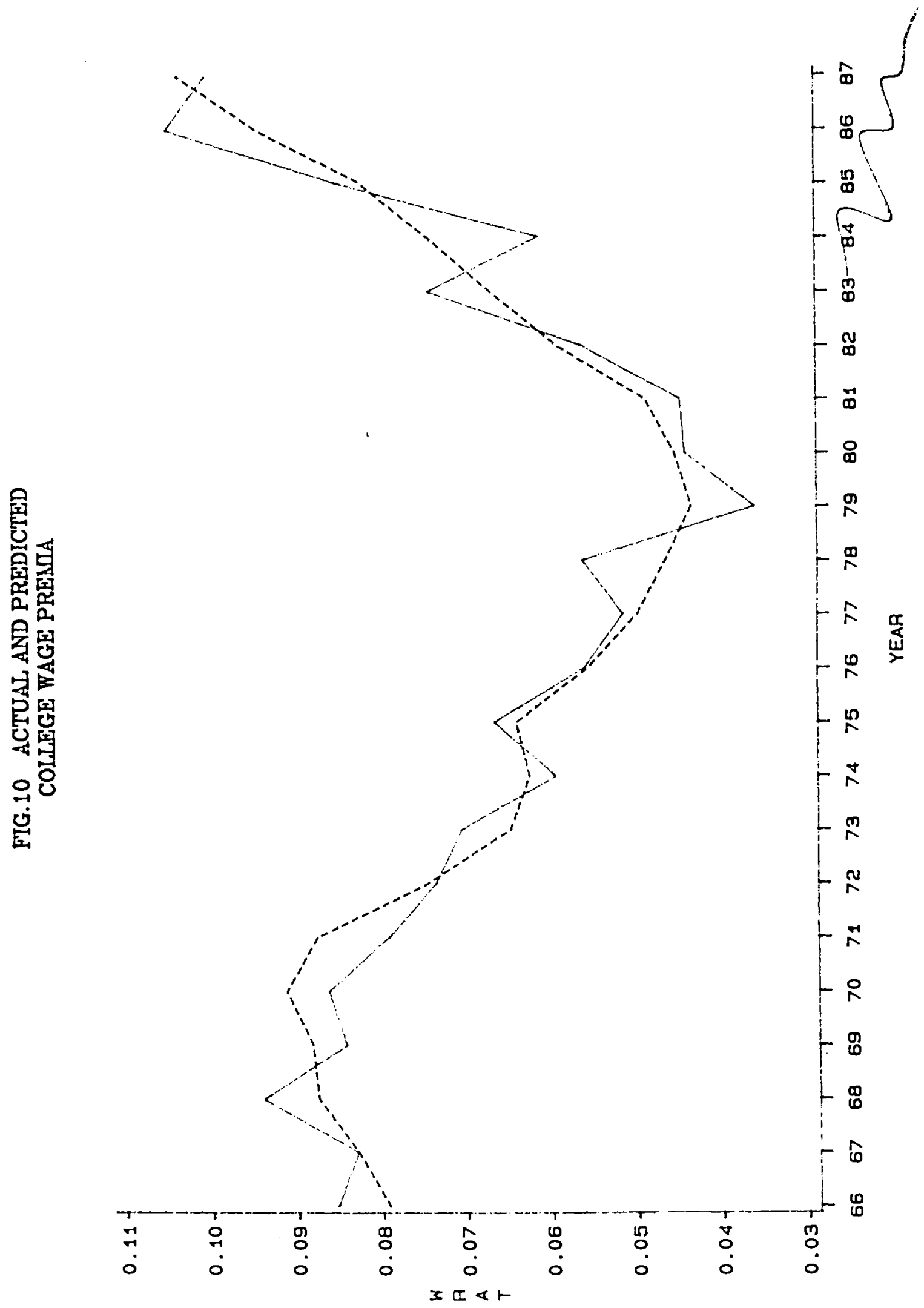

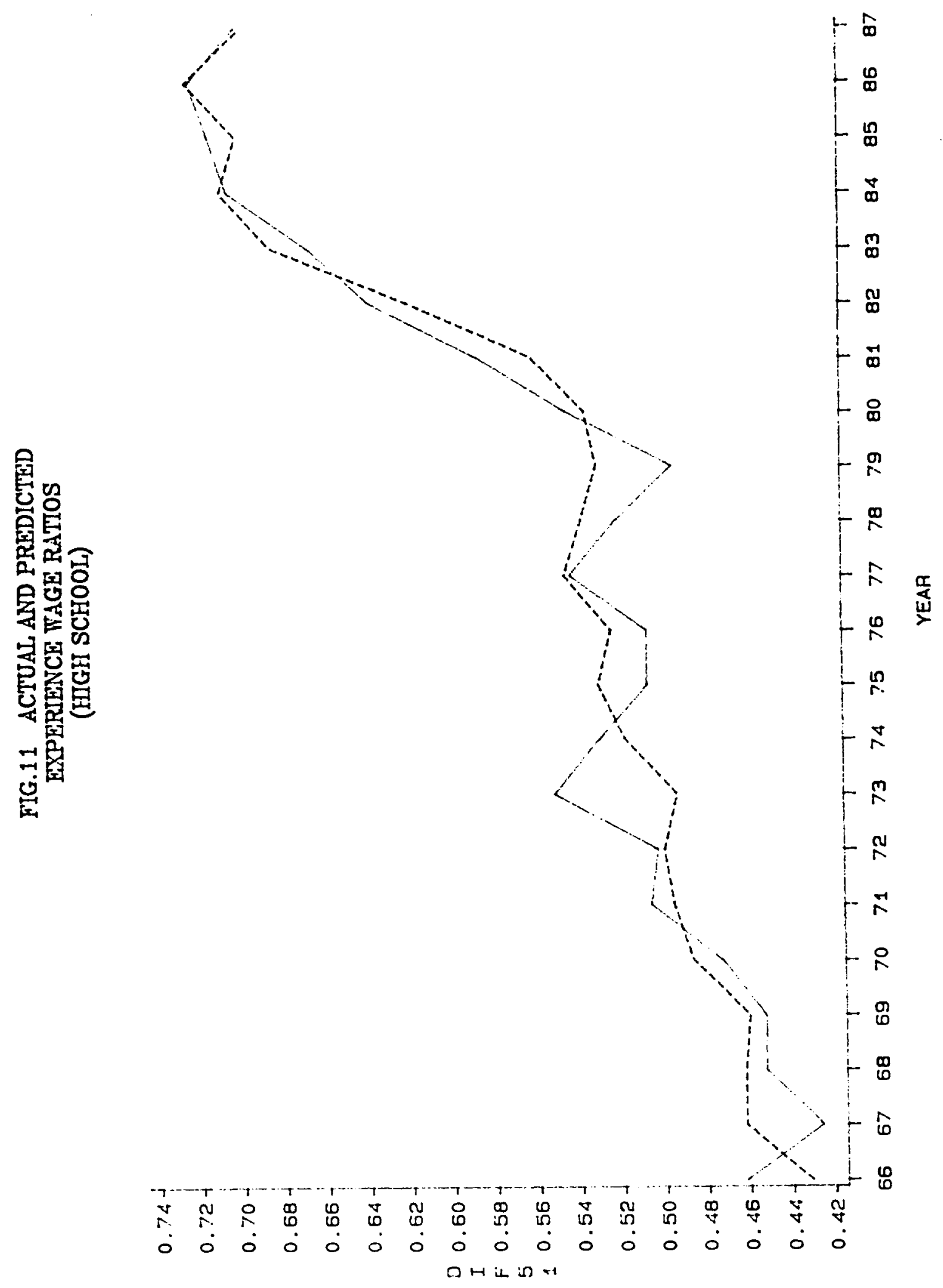

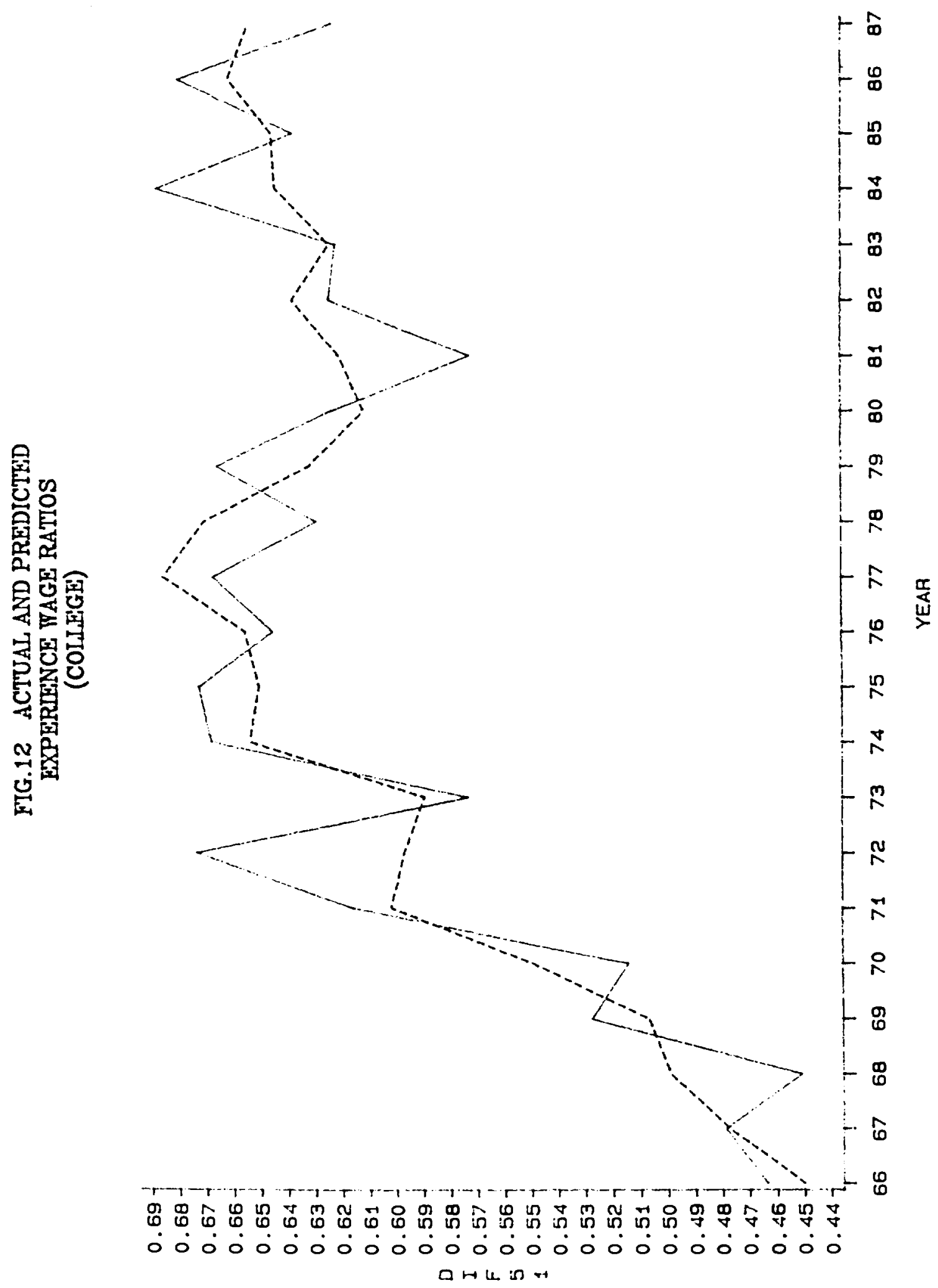